\title{
Financial Performance and Outreach: A Global Analysis of Leading Microbanks
}

\author{
Robert Cull (World Bank) \\ Asli Demirgüç-Kunt (World Bank) \\ Jonathan Morduch (New York University)
}

\begin{abstract}
Microfinance contracts have proven able to secure high rates of loan repayment in the face of limited liability and information asymmetries, but high repayment rates have not translated easily into profits for most microbanks. Profitability, though, is at the heart of the promise that microfinance can deliver poverty reduction while not relying on ongoing subsidy. We examine why this promise remains unmet for most institutions. Using a data set with unusually high-quality financial information on 124 institutions in 49 countries, we explore the patterns of profitability, loan repayment, and cost reduction. We find that institutional design and orientation matter substantially. Lenders that do not use group-based methods to overcome incentive problems experience weaker portfolio quality and lower profit rates when interest rates are raised substantially. For these individual-based lenders, one key to achieving profitability is investing more heavily in staff costs-a finding consistent with the economics of information but contrary to the conventional wisdom that profitability is largely a function of minimizing cost.
\end{abstract}

World Bank Policy Research Working Paper 3827, February 2006

The Policy Research Working Paper Series disseminates the findings of work in progress to encourage the exchange of ideas about development issues. An objective of the series is to get the findings out quickly, even if the presentations are less than fully polished. The papers carry the names of the authors and should be cited accordingly. The findings, interpretations, and conclusions expressed in this paper are entirely those of the authors. They do not necessarily represent the view of the World Bank, its Executive Directors, or the countries they represent. Policy Research Working Papers are available online at http://econ.worldbank.org.

The Mix Market provided the data through an agreement between the World Bank Research Department and the Consultative Group to Assist the Poor. Confidentiality of institution-level data has been maintained. We thank Isabelle Barres, Joao Fonseca, Didier Thys, and Peter Wall of the Microfinance Information Exchange (MIX) for their substantial efforts in assembling both the adjusted data and the qualitative information on MFIs for us. We have benefited from comments from Thorsten Beck, Patrick Honohan, Stijn Claessens, and participants at the Groningen conference. Sarojini Hirshleifer provided expert assistance with the research. 


\section{Introduction}

The economics of information shows how information asymmetries undermine credit markets in places where potential customers have few assets to offer as collateral (e.g., Besley, 1995). But microfinance would be a grand failure if this was all there was to it. Innovative contracts and new microfinance management practices have proven capable of generating high loan repayment rates in contexts as diverse as the slums of Dhaka, wartorn Bosnia, and rural Senegal. In doing so, microfinance practitioners have forced economic theorists to re-think pessimistic views on the prospect for lending profitably to the poor.

Recent theoretical work describes how these innovations work to secure loan repayments, but the analyses focus on only one part of the relevant equation. ${ }^{1}$ Meeting the full promise of microfinance — to reduce poverty without ongoing subsidies—requires translating high repayment rates into profits, a challenge that remains for most microbanks. ${ }^{2}$ The overall equation linking capital and labor inputs into profits and social change still proves difficult to master.

We take a close look at this equation with unusually high-quality financial information on 124 institutions in 49 countries; the institutions are united by claiming strong commitments to achieving financial self-sufficiency and a willingness to open

\footnotetext{
${ }^{1}$ A great deal has been written on microfinance theory within the past fifteen years (e.g., Stiglitz, 1990; Banerjee, Besley, and Guinnane, 1994; Besley and Coate, 1995; Conning, 1999; Ghatak and Guinnane, 1999; Laffont and Rey, 2003; and Rai and Sjöström, 2004). Armendariz de Aghion and Morduch (2005) provide a critical guide to the economics literature on microfinance.

${ }^{2}$ We take this goal on face value, although we recognize the case for subsidized microfinance when social benefits sufficiently outweigh social costs and subsidies do not undercut non-subsidized firms. The goal of profit-making microfinance is discussed by Robinson (2003). Armendariz de Aghion and Morduch (2005) discuss subsidy and sustainability in their chapter 9 .
} 
their accounts to careful scrutiny. ${ }^{3}$ The institutions thus represent some of the best hopes for achieving poverty reduction with profit (or at least without ongoing subsidy). Still, the average share of funding (total liabilities plus total equity) made up of subsidized resources exceeds 20 percent in this sample.

Empirical progress on understanding the trade-offs in microfinance has been held back by the lack of variation in prices and program elements necessary for identification of key parameters. Most financial institutions offer their clients a uniform set of products and they seldom change the product mix, price, or design—or institutions change policies in ways that make it difficult for researchers to disentangle patterns of product changes versus other contemporaneous changes. ${ }^{4}$ The cross-country data here, however, provide substantial variation in contractual types, prices, institutional sizes and locations, and target markets. The variation provides a means to describe the nature and trade-offs of lending relationships.

The data set allows us to examine several important claims for the first time in a large comparative survey. Does raising interest rates exacerbate agency problems as detected by lower loan repayment rates and less profitability? Is there evidence of a trade-off between the depth of outreach to the poor and the pursuit of profitability? Has “mission drift” occurred-i.e., have microbanks moved away from serving their poorer clients in pursuit of commercial viability?

\footnotetext{
${ }^{3}$ The data were collected as part of the MicroBanking Bulletin project. Summary statistics on the institutions have been made available in the Bulletin. This paper is based on the underlying data set, access to which has kindly been provided (with confidentiality safeguards) to the authors. The Bulletin is available at www.mixmarket.org.

${ }^{4}$ New work using field experiments (e.g., Karlan and Zinman, 2005) or natural experiments (e.g., Dehejia, Montgomery, and Morduch, 2005) shows promise in ways to either exploit the variation that exists or to create variation as part of a research program.
} 
As with other cross-country analyses, the aim is to describe patterns in the data. There is insufficient exogenous variation in key variables to reliably estimate causal impacts, so we focus on associations that can help illuminate and frame key debates, while bearing in mind that the institutions in the survey are more focused on financial performance than typical microbanks. We thus expect that the trade-offs described below are even starker for institutions that did not participate in the survey.

Our results bring some good news for microfinance advocates. First, over half of the institutions in the survey were profitable after accounting adjustments were made (although the average return on assets is negative overall). Others are approaching profitability and should be able to soon achieve financial self-sufficiency. Second, simple correlations show little evidence of agency problems, outreach-profit trade-offs, or mission drift. The correlations thus attest to the possibility of raising interest rates without undermining repayment rates, to achieving both profit and substantial outreach to poorer populations, and to staying true to initial social missions even when aggressively pursuing commercial goals.

Disaggregating by lending type, though, uncovers trade-offs and tensions, even among these leading institutions. The pattern of profitability and the nature of customers vary considerably with the design of the institutions and their contracts. Microfinance lenders use a variety of approaches to lending, and we focus on three main categories. The best-known approach is "group lending," made popular within microfinance by the Grameen Bank of Bangladesh and BancoSol in Bolivia. The method uses self-formed groups of customers that assume joint liability for the repayment of loans given to group members. The joint liability contract can, in principle, mitigate moral hazard and adverse 
selection by harnessing local information and enforcement possibilities and putting them to use for the bank. Another method is village banking, based on larger groups but a similar notion of joint liability. The third main method is "individual-based lending," which draws on traditional banking practices and involves a standard bilateral relationship between the bank and customer—and, absent other interventions, is most vulnerable to problems imposed by information asymmetries and weak enforcement capacities.

The data set contains institutions representative of each approach: 20 institutions based on village banks, 56 individual-based lenders, and 48 group-based lenders. Our findings on the latter two groups are generally robust across specifications.

Consistent with predictions from the economics of information, direct evidence on loan repayments shows that the fraction of a lender's portfolio at risk rises with interest rates for most of the 50 institutions based on individual-based lending. We also find that raising interest rates beyond a certain point (60 percent in our estimates) is associated with lower profits for individual-based lenders. The predictions are consistent, for example, with the landmark analysis of adverse selection by Stiglitz and Weiss (1981).

Investing relatively more in the workforce is also associated with greater profit for individual-based lenders. The result is consistent with the theoretical prediction that, since individual-based lenders cannot rely on the customers themselves to help with screening and monitoring (as under a group method), individual-based lenders must 
invest relatively more in staff costs to achieve higher levels of profit. As predicted, neither of these relationships holds in this sample for group lenders. ${ }^{5}$

Why is the individual-based approach ever favored over either of the group-based methods? We show that the individual-based lenders here provide substantially largersized loans (five times as large, on average). Loan size is typically taken as a proxy for poverty levels of customers, and the evidence suggests that for customers who are less poor and who are willing and able to invest in larger businesses, the group methods become cumbersome. Working with relatively few customers each with larger loans can be a path to financial self-sufficiency for lenders.

Taking this path veers from the traditional focus of microfinance (with its emphasis on making smaller loans at as wide a scale as possible), but the shift could improve overall welfare: it is not just the poorest that demand and can take advantage of better access to finance. Moreover, we find some evidence of "reverse mission drift" for individual-based lenders as a class: i.e., pursuing higher profits and focusing on poorer customers can go hand in hand. At the same time, the data show that larger microbanks on average have lower measures of outreach. In sum, there appears to be a trade-off in the breadth of outreach and the depth of outreach. The question remains open as to whether larger institutions serve an absolutely greater number of the very poor--a question that can only be answered with disaggregated data.

\footnotetext{
${ }^{5}$ Increasing labor costs are associated with greater profitability for the 20 village banks as well, which, relative to the pattern of other results, is not consistent with predictions.
} 


\section{Data and empirical approach}

The data on 124 microfinance institutions (MFIs) in 49 developing countries were collected by the Microfinance Information Exchange (or the MIX), a not-for-profit private organization that aims to promote information exchange in the microfinance industry. ${ }^{6}$ The database contains one observation per institution from 1999 to 2002. Seventy percent of the observations are from 2002. These data, collected for publication in the MicroBanking Bulletin (MBB), have been adjusted to help ensure comparability across institutions. The adjustments, which are summarized in Appendix A, include an inflation adjustment, a reclassification of some long-term liabilities as equity, an adjustment for the cost of subsidized funding, an adjustment for current-year cash donations to cover operating expenses, an in-kind subsidy adjustment for donated goods and services, loan loss reserve and provisioning adjustments, some adjustments for writeoffs, and the reversal of any interest income accrued on non-performing loans.

The institutions have been selected based in large part on the quality and extent of their data. The data set is thus not representative of all microfinance institutions. They do, however, collectively serve a large fraction of microfinance customers worldwide. A sense of the skewed size distribution of microfinance is given by Honohan's (2004) analysis of data provided by the Microcredit Summit organization, a data set whose top end largely overlaps the data here. Honohan (2004, p. 3) finds that "the largest 30

\footnotetext{
${ }^{6}$ Information on the MIX is available at their website www.themix.org. Data for institutions is available via the MIX MARKET, a global, web-based, microfinance information platform accessible via the MIX's website. The MFI data include outreach and impact data, financial data, audited financial statements, and general information. The MIX MARKET, previously known as "The Virtual Microfinance Market," began as a project of the United Nations Conference on Trade and Development (UNCTAD). The project was supported by the government of Luxembourg under the guidance of a sector-wide microfinance Advisory Board. In 2001, the Consultative Group to Assist the Poor (CGAP), a consortium of donors that promotes microfinance worldwide, expanded the scope of the MIX MARKET in collaboration with UNCTAD. The MIX currently receives support from CGAP, the Citigroup Foundation, the Open Society Institute, the Rockdale Foundation, and other private foundations.
} 
microfinance firms account between them for more than 90 per cent of the clients served worldwide by the 234 top firms (and hence for more than three-quarters of those served by all of the 2572 firms reporting to the Microcredit Summit).” While we cannot make a similar comparison here, Honohan's evidence suggests that during the sample period the banks here served over half of all microfinance customers worldwide.

An important feature of our data is qualitative information on the lending style employed by the MFI, the range of the services it offers, its profit status, ownership structure, and sources of funds. These detailed data enable us to offer a more complete analysis of MFI performance by lending type than has been possible before. ${ }^{7}$ Lending methods vary across regions, as shown in Table 3. There are no village banks in East Asia in the sample, for example. Individual-based lending predominates in East Asia and the Pacific, while institutions in South Asia and Sub-Saharan Africa tend to lend through group mechanisms. Institutions in Eastern Europe and North Africa do not strongly favor either individual-based or group lending.

Summary statistics at the bottom of Table 1 indicate that, with the possible exception of Latin America and the Caribbean (LAC), our sample is reasonably balanced across regions. Seventeen percent of the institutions come from Eastern Europe and Central Asia, another seventeen from Sub-Saharan Africa (AFR). South Asian (SA) institutions comprise ten percent of the sample, while institutions from East Asia and the Pacific (EAP) and the Middle East and North Africa (MENA) comprise nine and seven percent, respectively. ${ }^{8}$ Institutions from Latin America and the Caribbean comprise forty

\footnotetext{
${ }^{7}$ For example, Hartaska and Nadolnyak (2005) use a subset of the MIX data to investigate whether the regulatory environment affects the operational self-sustainability and outreach of MFIs, but they are unable to disaggregate by lending type and their self-sustainability measure is unadjusted.

${ }^{8}$ The regional classifications and acronyms are those employed by the World Bank.
} 
percent of the sample. Although we include regional dummy variables in the regressions that follow, the regional preferences for certain lending types should be kept in mind when interpreting results.

Dependent variables. The key dependent variable in our analysis of profitability is the financial self-sufficiency (FSS) ratio, a measure of an institution's ability to generate sufficient revenue to cover its costs. ${ }^{9}$ Values below one indicate that it is not doing so. We prefer the financial self-sufficiency ratio to other measures of financial performance because the data are adjusted as described above, and because it offers a more complete summary of inputs and outputs than standard financial ratios such as return on assets or equity. For robustness, however, we also use as dependent variables an unadjusted measure of operation self-sufficiency (OSS) and a measure of adjusted return on assets (ROA). ${ }^{10}$

Many of the explanatory variables that we use also contain extreme values as summarized in Table 1. The correlations between FSS, OSS, and ROA are positive and significant, but not perfect (ranging from .59 to .90). The three measures are also similarly correlated with a number of our explanatory variables. For example, the age and size of institutions are significantly correlated with all three performance measures (Table 2). Regression analyses allow us to investigate the strength of those correlations after controlling for region, lending type, and other relevant covariates.

\footnotetext{
${ }^{9}$ The financial self-sufficiency ratio is adjusted financial revenue divided by the sum of adjusted financial expenses, adjusted net loan loss provision expenses, and adjusted operating expenses. It indicates the institution's ability to operate without ongoing subsidy, including soft loans and grants. The definition is from MicroBanking Bulletin (2005), p. 57.

${ }^{10}$ The operational sustainability ratio is financial revenue divided by the sum of financial expenses (unadjusted for implicit subsidies), net loan loss provision expenses, and operating expenses. It indicates the institution's ability to operate without subsidy and without drawing down capital to pay for operating expenses. Unlike the financial self-sufficiency ratio, the OSS is not adjusted. Return on assets is measured as adjusted net operating income (net of taxes) divided by adjusted average total assets. Definitions are from MicroBanking Bulletin (2005), p. 57.
} 


\section{The Microfinance Landscape}

Figure 1 shows basic patterns across the three main institutional types identified in the survey:

1. "Individual-based lenders": institutions that use standard bilateral lending contracts between a lender and a single borrower. Liability for repaying the loan rests with the individual borrower only, although in some cases another individual might serve as a guarantor;

2. "Solidarity group lenders": institutions that employ contracts based on joint liability implemented with "solidarity groups” (in the spirit of contracts used initially at the Grameen Bank in Bangladesh and at BancoSol in Bolivia). Loans are made to individuals, but the group, which has between 3 and 10 members depending on the institution and location, shoulders responsibility for a loan if a member cannot repay, and

3. "Village banks," where each branch forms a single, large group and is given a degree of self-governance (this kind of arrangement was pioneered by FINCA and is now employed by organizations like Pro Mujer and Freedom from Hunger).

Figure 1 shows that patterns of average revenues and costs vary systematically by lending type. The village banks in the survey charge the highest average interest rates and face the highest average costs. The measure captures both direct interest charges and 
any additional fees charged by lenders. The total expense ratio gives the ratio of total expenses (including labor and capital costs) to assets.

Costs outweigh interest revenues, though, and the result is that the average return on assets for village banks is negative $(-0.08)$. The microbanks using solidarity groups charge lower interest rates and face lower costs, but again costs exceed revenues and the average return on assets is -0.05 . Only for the individual-based lenders in the survey is the average return on assets positive, though small (0.01).

These patterns reflect differences in social mission, target customers, and location as much as management strategies. The summary statistics show, for example, that a reason that costs are so much higher for village banks and group lenders (relative to individual-based lenders) is that they make smaller-sized loans and serve poorer populations. The data in Table 4 show that village banks, the least profitable lending type as a class, serve the poorest customers (as proxied by loan size) and their clients are more likely to be women. The customers of village banks and group lenders, for example, are largely women: 88 percent and 75 percent, respectively. In comparison, just under half of the customers of individual-based lenders are women (46 percent).

The village banks in the survey also make the smallest-sized loans (\$149 on average), followed by group lenders (\$431). Individual-based lenders made far larger average loans on average (\$1220). ${ }^{11}$ Average loan size is often taken to be a proxy for the poverty of customers, and these results are in line with anecdotal evidence about the depth of outreach across lending types. The loan size comparisons are made at official exchange rates, though, which can substantially distort the purchasing power of a given amount of money in local currency. Patterns are broadly similar, however, even if the

\footnotetext{
${ }^{11}$ The numbers in this section are from Table 4 below.
} 
average loan sizes are deflated by gross national product per capita (a metric often preferred by microfinance donors) or deflated by the average income per capita of the bottom 20 percent in the country. For average loan size to GNP per capita, the ratio for village banks: solidarity group lenders: individual-based group lenders is 0.20: 0.54: 1.01 . Where the deflator is the average income per capita of the bottom 20 percent in the country, the ratios are $0.63: 1.63: 4.80$. These basic distinctions by lending type play out in important ways in the regression analyses below.

Table 5 shows that village banks as a class take advantage of subsidies to a greater extent than others. The average fraction of subsidies in funding (total liabilities plus total equity) is over one-third. For solidarity group-based institutions, the fraction is $28 \%$, and for individual-based lenders the subsidized share of funding is just $11 \%$.

Not surprisingly, receiving more subsidies is negatively correlated with profitability. Table 6 shows the sample average correlation coefficient with respect to financial self-sufficiency is (-.28), and (-.53) with respect to returns on assets.

\section{Regression approach}

The aim of the benchmark regressions is to understand why some microbanks have achieved profitability while others have remain reliant on subsidy. The base regressions thus describe the correlates of profitability, focusing particularly on the roles of costs and interest rates charged on loans. We allow these factors to vary by lending type using the following reduced-form equation: 
$F S S_{i}=\alpha+\beta_{1}$ Yield $+\beta_{2}^{\prime}$ Yield $*$ LendingType $+\beta_{3}^{\prime}$ Cost $+\beta_{4}^{\prime}$ Cost $*$ LendingType $+\beta_{5}^{\prime}$ LendingType + $\beta_{6}^{\prime}$ MFIhistory $+\beta_{7}^{\prime}$ orientation $+\beta_{8}^{\prime}$ region $+\varepsilon_{i}$

(1)

where FSS is the financial self-sufficiency ratio of microfinance institution $i$, and Yield is the real gross portfolio yield, a measure of interest charges faced by customers, as described in Table 1. ${ }^{12}$ The gross portfolio yield is the ratio of interest revenues to the average size of the loan portfolio. Because loan losses are not netted out of the revenues, this measure is intended to capture the ex-ante interest rate charged by the MFI rather than the ex-post interest rate realized on the portfolio. The coefficient matrix $\beta_{2}$ includes coefficients that show how the effects of Yield vary by lending type, described in greater detail below. In the results that follow, the omitted category is "individual-based lenders”. Thus, there is one Yield coefficient for solidarity group lenders and another for village banks. Each of those coefficients measures the difference between that lending type and individual-based lenders with regard to the effect of yields. The coefficient $\beta_{1}$ thus summarizes the effect of yields on financial self-sufficiency for individual-based lenders.

The Cost matrix is comprised of two variables, one measuring capital costs relative to assets, the other for labor costs to assets. Like the yield variable, these two cost variables are interacted with the lending type variables. The lending type variables also enter the specification independently. Because they again are the omitted category, individual-based lenders do not have their own coefficient. The matrix MFI history

\footnotetext{
${ }^{12}$ The means and medians for FSS, OSS, and ROA are all within the expected range (Table 1), but the minimum and maximum values suggest a wide range for each variable, and thus outliers will be a concern in the analysis that follows, prompting the use of robust regression methods as a check on robustness to outliers.
} 
includes two variables, one for age and the other for size (as measured by total assets). The matrix Orientation contains three variables that describe the microfinance institution's business practices: the ratio of loans to assets, the average loan size (relative to GNP per capita), and a dummy variable indicating the institution's formal profit status (equal to one if the organization is for-profit). Finally, region is a matrix of dummy variables for each main region of the developing world, with "Latin America and the Caribbean" as the omitted category.

Having summarized the correlates of profitability, the next set of regressions explores the relationship of interest rates and costs for each lending type. We first introduce a quadratic term for the gross portfolio yield variable in the profitability equations, allowing the quadratic effect to differ across lending types. The quadratic form can generate U-shaped patterns consistent with the prediction that agency problems become so severe that overall profitability falls as interest rates rise beyond a point. This result is also consistent with falling demand for credit (and thus diminishing scale economies) at high interest rates. To shed further light on the hypothesis from agency theory, we then replace the profit measures with the share of the portfolio that is delinquent (portfolio at risk) to test directly whether high interest rates are associated with higher rates of non-repayment—and find that they are, but only for individual-based lenders. Moreover, individual-based lenders charging the highest interest rates in our sample enjoy better repayment performance than those charging intermediate rates. Yet, their lending volumes are substantially lower, a finding that is more consistent with falling demand for credit as rates push past threshold values than with predictions from agency theory. 


\section{Results}

\section{Financial sustainability}

Table 7 gives the results from the estimation of equation 1 above. The results show that raising interest rates is associated with improved financial performance for individualbased lenders only. The coefficient for real gross portfolio yield (the measure of average interest rates on loans to customers) is positive and significant across all three profitability indicators (financial self-sufficiency, operational sustainability, and return on assets), indicating that individual-based lenders tend to be more profitable when their average interest rates are higher.

The result, in itself, is not surprising, but the same result does not hold for village banks or solidarity group lenders. When summed, the coefficients for yield and the yield interactions are not significantly different from zero. Thus, for both types of group lenders there is not a significant relationship between interest rates and profitability, even after controlling for costs.

We find that labor costs are associated with improved profitability for individualbased lenders (for all three of our profitability measures). The labor cost interaction term for village banks is positive but not significant in all specifications, indicating no significant difference between them and individual-based lenders. ${ }^{13}$ Thus, these two types of lenders tend to more than recoup the costs they devote to personnel. One possibility, which we explore below, is that identifying creditworthy borrowers is laborintensive. Once identified, however, such borrowers receive relatively large loans, making this a cost-effective strategy.

\footnotetext{
${ }^{13}$ The labor costs and village bank*labor costs coefficients are also jointly significantly greater than zero in all specifications in Table 7.
} 
Group lenders do not follow this strategy. The coefficient on their labor costs variable is negative, significant and of similar magnitude to the simple labor costs variable (corresponding to individual-based lenders). When summed, the coefficients are not significantly different from zero at the $\mathrm{p}=.05$ level for any model in Table 7 , indicating no strong relationship between labor costs and financial performance.

Not surprisingly, the benchmark regression shows that rising capital costs reduce profitability for individual-based lenders. The coefficients on the capital costs variables also show differences in the way the three types of lenders generate profits. As hypothesized, capital costs (which include rent, transportation, depreciation, office, and other expenses) are negatively linked to profitability measures. Therefore, this method of cost containment is associated with profit, at least for individual-based lenders.

For village banks, rising capital costs are associated with an even sharper decline in profitability. The interaction term for village banks is negative and often significant, suggesting that high capital costs hurt their bottom line even more than that of individualbased lenders. When summed, the capital costs and village bank*capital costs coefficients are significantly less than zero (at the $\mathrm{p}=.01-.06$ level) for all specifications in Table 7. The result suggests that village banks have less room to adjust in the face of rising costs. But we find no significant relationship between capital costs and profitability measures for group lenders.

Note that neither the village bank nor the solidarity group dummy variable is significant in Table 7, indicating that once the effects of costs and yields are permitted to vary by lending type, those types explain no additional variation in financial performance. The regional dummy variables do explain some variation in financial 
performance. Institutions from Eastern Europe and Central Asia and those from South Asia out-performed those from other regions in terms of financial self-sufficiency. An institution's age and size are significantly positively linked to financial performance across all three indicators. ${ }^{14}$ Finally, neither the indicator for being constituted formally as a for-profit bank nor the average loan size variable are strongly linked to the financial performance indicators. The latter result shows that, even after controlling for region and other covariates, institutions that make smaller loans are not less profitable on average. ${ }^{15}$

Given the maximum and minimum values for our variables in Table 1, there is some concern that outliers partly drive the results. We therefore use a robust estimation technique that weights observations based on the absolute value of their residuals, in which observations with large residuals are assigned smaller weights (Appendix B Table 1). ${ }^{16}$ Those results are similar to the base results, although there are a few minor differences. First, the coefficient on the portfolio yield is no longer significant in the OSS specifications, which could be because outliers were driving that result in Table 7. This also could be an indication of the importance of the adjustments to the raw data made by the MIX. That is, the unadjusted OSS data might have included outliers that drove a spurious positive correlation with yields. In any event, the yield coefficient in the FSS and ROA regressions remains positive and significant. The coefficients and significance levels for the costs variables are also similar to the base specifications, as are the

\footnotetext{
${ }^{14}$ In addition to controlling for age in the base regressions, we also ran models on subsets of MFIs of similar vintage (5-20 years old). Because the performance indicators for young MFIs are widely dispersed, our results are at least as strong when we restrict the sample in this way. See Appendix A for reasons why data from young MFIs might be most in need of adjustment.

${ }^{15}$ The basic pattern of results also holds when we control for regional variation in different ways. For example, in unreported specifications we allowed for correlation between observations from the same country using clustered standard errors. In another set of unreported specifications, we allowed for random effects at the country level. Given the small size of our dataset, we were not able to incorporate country fixed effects in our models. See Deaton (1997, pp. 73-78) for a detailed discussion of clustering.

${ }^{16}$ We use the "rreg" command in STATA.
} 
significance levels for age and size (though their coefficients are a bit smaller). In general, the robust regression results reinforce our original conclusions.

\section{Interest rates}

The regressions in Table 7 report the average association between portfolio yields and financial performance. The results can be extended to shed light on the implications of agency theory. Specifically, when lenders face informational asymmetry and borrowers lack collateral, charging interest above a certain threshold could aggravate problems of adverse selection. At such rates, only low-quality borrowers that do not expect to be able to repay would find it in their interest to borrow. If these conjectures are true, one would expect to see them reflected in lower repayment rates and profitability for microbanks charging relatively high interest rates.

We test these ideas by including the square of portfolio yield in our base specifications. As in previous specifications, we allow the association between the squared yield variable and financial performance to vary by lending type. We have a relatively small dataset, so that introducing the squared yield terms makes it difficult to allow separate labor and capital costs variables for each lending type. Therefore, those costs variables enter the specifications in Table 8 without lending type interactions, and are insignificant. Note that when the costs variables are collapsed in this way, the simple dummy variable for group lending becomes positive and significant across profitability indicators.

The results follow the theoretical predictions for individual-based lenders. The main finding from Table 8 is that for individual-based lenders, financial self-sufficiency 
and operational sustainability are increasing in portfolio yield, but only up to the point at which the negative quadratic yield coefficient outweighs the positive linear coefficient. ${ }^{17}$ Both the linear and the squared yield variables are significant. Figure 2 plots the estimated relationship between the financial self-sufficiency ratio and the yield ratio based on Table 8, model 3, for an individual-based lender assigned the median value for all other variables that enter the regression. As hypothesized, financial self-sufficiency is increasing in yield up to a point. That break point occurs within our sample values for portfolio yields for individual-based lenders (60\% percent per annum). However, only one individual-based lender had a portfolio yield greater than that value. The result is consistent with individual-based lenders adjusting in order to avoid potential incentive problems, and thus opting not to push interest rates beyond threshold values.

For village banks, coefficients on both the linear and squared yield variables are not statistically significant, but similar in magnitude to, and the opposite sign of, the simple yield variables (corresponding to effects for individual-based lenders). Summing the respective squared and linear variables, there is no significant relationship between yields and our profitability indicators for village banks.

For group lenders, the coefficients for yield and yield squared are also the opposite sign of those for individual-based lenders, but they are much larger in magnitude. When the respective coefficients are summed, the yield coefficients are negative and significant, while the coefficients for yield squared are positive and significant. The result is Figure 3, which displays a U-shaped relation between yields and

\footnotetext{
${ }^{17}$ Note that the models in Table 8 are run via OLS, with White's standard errors. Similar qualitative results were obtained for robust regressions, although significance levels were lower. Because we are trying to illustrate the effect of relatively extreme portfolio yields, the OLS models were more appropriate than robust techniques that were likely to downweight such observations.
} 
financial self-sufficiency. For portfolio yields under $40 \%$ per annum, which characterizes the majority of solidarity group lenders in our sample, the relationship is negative. Had we not imposed the non-linearity by including a separate squared yield term for group lenders, the simple linear relation between financial self-sufficiency and yield would have been negative.

Overall, the results in Table 8 suggest that individual-based lenders that charge higher interest rates are more profitable than others, but only up to a point. ${ }^{18}$ For most solidarity group lenders, the reverse seems true. Their financial performance is worse at higher yields.

Below, we ask how much of this pattern is related to rising loan delinquency. Throughout most of our sample range, loan delinquency is more common for individualbased lenders that charge higher yields (as predicted by theory). However, the evidence is more consistent with falling demand at the highest interest rates charged by our individual-based lenders_-which in turn reduces scale and, ultimately, profitability. Again, as predicted, we do not find evidence that profitability is lower at high interest rates for group lenders, nor is there a significant relationship between yields and portfolio quality.

\section{Portfolio at risk}

Direct insight into agency problems comes from analyzing determinants of loan delinquencies and their relation to interest rates. Again, we find an inverted U-shaped pattern for individual-based lenders. Table 9 presents the regressions that relate yields to portfolio at risk. We replace the dependent variables in the Table 8 regressions with the

\footnotetext{
${ }^{18}$ The result could be due to reverse causation. Reducing interest rates (and thus lowering profits) might be especially likely when the institution is driven by social objectives or if it seeks to maximize profits but faces potential competition.
} 
share of the portfolio that is at risk, defined as the share of loans that are delinquent for at least thirty days. Although the significance of the yield variables depends on the inclusion of the loans to assets ratio and the for-profit dummy in the specification, the non-linearities implied by the profitability models also appear in the portfolio at risk regressions for individual-based lenders. Summing the respective squared and linear yield variables, there is no significant relationship between yields and portfolio risk for group lenders or village banks.

When we plot the relation between yields and portfolio at risk for individualbased lenders (see Figure 4), there is a positive relation up to real yields of about 45 percent. Beyond that point, however, the share of loans at risk is declining in portfolio yield, and 7 to 9 individual-based lenders have yields that high. Reconciliation with the earlier results (showing a downturn in profitability only when real yields surpass about 60 percent) comes from taking demand also into account. From Table 1 we know that the portfolio yield variable is significantly negatively correlated with size of an institution (i.e., total assets) and the ratio of loans to assets, so there is a negative association between charging higher interest rates and having a large customer base. By the same token, there is also a significant negative correlation between real yields and average loan size (relative to GNP per capita), which indicates that high yield lenders tend to make small loans, another reason for seeing the downward pressure on profitability at very high yield rates. ${ }^{19}$

\footnotetext{
${ }^{19}$ Note, though, that the benchmark regressions show no general association of average loan sizes and financial sustainability.
} 


\section{Reducing costs}

For individual-based lenders (and village banks), the base results indicated that financial performance was positively linked to labor costs, but negatively linked to capital costs. We speculated that this could be a cost-effective strategy if the resources were used to identify creditworthy borrowers, who would then be given relatively large loans. To test that proposition, Table 10 offers regressions that relate the total cost per dollar lent to the microbank’s average loan size. We also include the square of average loan size to capture potential non-linearities. The question is the degree to which expanding loan sizes improves profitability by lowering average costs.

We find that larger loans are associated with lower average costs-but only up to a point. The loan size coefficient is negative and significant in both OLS and robust regressions, while loan size squared is positive and significant. The two coefficients imply a U-shaped relationship between costs per dollar lent and average loan size for individual-based lenders that reaches its minimum for loans two to three times per capita GNP (Figure 5). Note also that only a handful of individual-based lenders exceed the minimum.

Similar findings hold for group lenders, although they appear to be less able to exploit scale economies. For solidarity group lenders, coefficients for the loan size variables are significant and of the same sign as those for individual-based lenders, which also implies a U-shaped relationship between costs per dollar lent and loan size (Figure 6). However, the magnitudes of those coefficients imply a minimum at the level of GDP per capita. Based on the respective minima for the two groups, individual-based lenders seem better able to exploit these scale economies. 
The patterns for village banks are not robust to the specification. Results for village banks are, in general, estimated with less precision than those for the other types of lenders. In the OLS regressions in Table 10, the loan size variables tend to share the same signs as those for individual-based lenders, but are insignificant. In the robust regressions, the loan size coefficients are significant, large in magnitude, and of the opposite sign of those for individual-based lenders. Future work with a larger data set may lead to more robust estimates for village banks, but the present data do not provide a reliable guide to patterns. ${ }^{20}$

\section{Mission Drift}

Mission drift is a concern for socially-driven microbanks. As clients mature and develop their businesses, the clients should be able to increase loan sizes and their incomes should rise. A successful microbank will thus find that, over time, their clients receive larger loans and will be less poor. The bank's mission and practices may well need to shift with these changes, but the result is not "mission drift" as the term is generally understood.

Mission drift, instead, is a shift in the composition of new clients, or a reorientation from poorer to wealthier clients among existing clients. The evidence above shows that the concern can not be brushed away easily. In particular, tensions between outreach and sustainability emerged when results were disaggregated by lending type. Results from the section above suggest that individual-based lenders (and to a lesser extent group lenders) find it cost-effective to increase their average loan size. In pursuing profit, microbanks would then naturally ask whether it can make sense to shift focus to

\footnotetext{
${ }^{20}$ Lacking a firm basis for the choice of specification, we do not present a figure for village banks.
} 
wealthier borrowers who can absorb larger loans, even at the sacrifice of outreach to the poorest segments in a community.

The cross-sectional data here are not ideal for addressing mission drift since the issues inherently involve adaptation over time. We focus instead on the relationship between outreach and profitability, using a variety of outreach measures as dependent variables. Table 11 gives results on the relationship between profitability and three common measures of outreach: average loan size/GDP per capita, average loan size/GDP per capita of the poorest 20 percent of the population, and the share of loans extended to women. Smaller average loan size is taken as an indication of better outreach to the poor. Deflating by GDP per capita both normalizes the loan size variable so that it is no longer in terms of local currency and provides an adjustment for the overall wealth of a country. In high-inequality countries, GDP per capita is a poor reflection of typical resources for households, so normalizing instead by the income accruing to the bottom 20 percent should be a better denominator. It turns out, though, that the results are comparable across measures.

The first result is that, on average, financial self-sufficiency is not significantly linked to any of the outreach measures. This might suggest no mission drift (see models 1, 4, and 7 in Table 11). As in much of the rest of the paper, however, the relationship between profitability (financial self-sufficiency) and outreach only becomes apparent when we allow it to vary by lending type. When we do this, we find evidence of reverse mission drift for individual-based lenders. On the other hand, we also find that larger microbanks tend to have fewer poor customers and serve a greater fraction of men, rather than women. 
In specification 2 in the table, the interaction between profitability and lending type is positive and significant for both village banks and group lenders. ${ }^{21}$ This does not necessarily indicate that village banks and group lenders with relatively high profitability lend less to the poor. When we sum the coefficients for the profitability variable and the respective interaction terms, we find that profitability is not significantly linked to the average loan size indicators for either type of lender (i.e., there is no evidence of mission drift). However, once those interaction terms are included in the regressions, the coefficient for financial self-sufficiency (corresponding to individual-based lenders) becomes negative and significant for both average loan size variables in the robust regressions (see Appendix B, Table 2). ${ }^{22}$ This suggests that individual-based lenders that are financially self-sustaining tend to be more focused on the poor.

Countervailing trends emerge, though, when we push further by investing the role of institutions' age and size. The correlations in Table 1 indicate that a microbank's age and size are positively related to profitability. Thus, to better isolate the effect of financial self-sufficiency on outreach, we control for those two factors in models 3, 6, and 9 (both on their own and interacted with lending type). Table 12 offers an overview of those results.

\footnotetext{
${ }^{21}$ The positive relationship between FSS and outreach indicators in the simpler specifications (2, 5, and 8) is more pronounced in the specifications with the complete set of interactions (3, 6, and 9). Controlling for age and size by type of lender, individual-based lenders with relatively high FSS tend to have better outreach, an indication perhaps of reverse mission drift. For village banks and group lenders, FSS appears to have little effect on outreach. Their FSS coefficients are opposite in sign to that of the simple FSS variable, and the net effect of the two coefficients is not significantly different from zero (except for group lenders in the women borrowers specifications).

${ }^{22}$ In the yield regressions we highlighted the effects of extreme values on profitability and loan quality, and thus the OLS regressions were suitable. Here we summarize the average relationship between FSS and outreach measures, and thus the robust regressions provide helpful checks.
} 
The significant positive coefficients for institution size in the average loan specifications, and the significant negative coefficients in the specifications on gender, indicate that larger individual-based lenders do relatively poorly in terms of outreach. For village banks, the interaction with size produces coefficients of the opposite sign of those for the simple size variable. Because the magnitudes of the two sets of coefficients are similar, size is not significantly associated with outreach for village banks.

For group lenders, the size coefficients in the average loan size specifications are of the same sign as those for village banks, but the magnitudes are substantially smaller. The net effect of summing the coefficients for the size variable and the group lending*size interaction term is significantly greater than zero, indicating that large group lenders have larger average loan sizes. Similarly, when those coefficients are summed in the "women borrowers" specifications, the total effect is significantly less than zero, indicating that large group lenders lend less to women.

Controlling for financial self-sufficiency, age, and size by type of lending, village banks and group lenders have much smaller average loan sizes and extend a higher share of their loans to women (based on the coefficients for the simple dummy variables for those two groups). However, the interactions between lending type and age, size, and FSS reveal more complicated relationships than those dummy variables would suggest. The significant positive coefficient for age in the specifications for average loan size divided by the GNP per capita of the poorest $20 \%$ provides some evidence of mission drift over time for individual-based lenders. For village banks and group lenders, age appears to have less association with outreach. For example, in some specifications, neither the age variable nor the village bank*age interaction term is significant. In others, 
the age coefficient is positive and significant, while the interaction is negative and significant. The net effect of the two coefficients is never significantly different from zero.

In sum, outreach appears to be driven by two countervailing influences for individual-based lenders. Size (and to a lesser extent age) is associated with less outreach, while profitability is associated with more. On balance, the evidence suggests that, as they grow larger, individual-based lenders are more susceptible to mission drift than village banks. Outreach indicators for village banks and group lenders tend not to be significantly negatively associated with age, size, or financial self-sufficiency. For them, mission drift would appear to be a less severe concern, although large group lenders do have worse outreach than smaller ones.

\section{Conclusion}

At the outset of this paper, we sought to address three questions. Does raising interest rates exacerbate agency problems as detected by lower repayment rates and less profitability? Is there evidence of a trade-off between the depth of outreach to the poor and the pursuit of profitability? Has "mission drift” occurred-i.e., have microbanks moved away from serving their poorer clients in pursuit of commercial viability?

Based on a high-quality survey of 124 microfinance institutions, we find that the answers to our questions depend on an institution’s lending method. For example, regarding interest rates and profitability, we find that individual-based lenders that charge higher interest rates are more profitable than others, but only up to a point. ${ }^{23}$ Beyond

\footnotetext{
${ }^{23}$ Again, we acknowledge the possibility of alternative interpretations. For example, the social objectives of some MFIs might compel them to charge lower interest rates and thus reap lower profits. Those institutions might require substantial subsidies to operate, consistent with the negative correlations between
} 
threshold interest rates, profitability tends to be lower owing to greater loan delinquency (consistent with predictions from agency theory) and, at the highest rates, to falling demand for credit. In contrast, for solidarity group lenders financial performance tends to worsen as yields increase throughout our sample range.

Consistent with the economics of information, we also find that individual-based lenders with higher labor costs (as a fraction of total assets) are in fact more profitable. As loan sizes grow, we hypothesize that these lenders need to be especially careful about selecting and monitoring customers, requiring higher labor inputs. For solidarity group lenders, who harness local information to select and monitor customers, we find no significant relationship between labor costs and profitability.

On our second question, regarding trade-offs between outreach to the poor and profitability, we find that larger loan sizes are associated with lower average costs for both individual-based lenders and solidarity group lenders. Since larger loan size is often taken to imply less outreach to the poor, the result could have negative implications. However, scale economies are exhausted at relatively low average loan sizes for group lenders. For individual-based lenders, the pattern of results might be consistent with more troubling interpretations - the personnel expenses devoted to identifying borrowers worthy of larger loans could make them less apt to serve the poorest segments of society. Yet, this shift in emphasis could also be welfare enhancing because it is not just the poorest that demand and can take advantage of better access to finance.

Moreover, in our base regressions the simple relationship between profitability and average loan size is insignificant. Controlling for other relevant factors, institutions

subsidies and profitability in Table 6. However, this would not explain the trade-offs we find for MFIs charging relatively high yields. 
that make smaller loans are not necessarily less profitable. We also find some positive results for individual-based lenders regarding mission drift, the third issue we sought to address. Financially self-sustaining individual-based lenders tend to have smaller average loan size and lend more to women, suggesting that pursuit of profit and outreach to the poor can go hand in hand. There are however countervailing influences: larger individual-based and group-based lenders tend to extend larger loans and lend less frequently to women. Older individual-based lenders also do poorer on outreach measures than younger ones. While this is not evidence of mission drift in the strict sense (i.e., that pursuit of improved financial performance reduces focus on the poor), the results for larger and older microbanks are consistent with the idea that as institutions mature and grow, they might focus increasingly on clients that can absorb larger loans.

On the whole, our results suggest that institutional design and orientation matters importantly in considering trade-offs in microfinance. The results underscore the need to better understand how contracts function using detailed micro data. 


\section{References}

Armendáriz de Aghion, Beatriz (1999). “On the Design of a Credit Agreement With Peer Monitoring”, Journal of Development Economics 60: 79-104.

Armendáriz de Aghion, Beatriz and Jonathan Morduch (2005). The Economics of Microfinance. Cambridge, MA: MIT Press.

Banerjee, Abhijit, Timothy Besley, and Timothy Guinnane (1994). “Thy Neighbor's Keeper: The Design of a Credit Cooperative with Theory and a Test," Quarterly Journal of Economics 109 (2), May: 491-515.

Besley, Timothy (1995). “Savings, Credit, and Insurance,” Handbook of Development Economics, Volume 3A, Chapter 36. Amsterdam: North-Holland.

Conning, Jonathan (1999). "Outreach, sustainability and leverage in monitored and peermonitored lending,” Journal of Development Economics 60: 51-77.

Dehejia, Rajeev, Heather Montgomery, and Jonathan Morduch, (2005). "Do interest rates matter? Evidence from the Dhaka slums.” Columbia University, Department of Economics and NYU Wagner School working paper.

Ghatak, Maitreesh (2000). "Screening by the Company You Keep: Joint Liability Lending and the Peer Selection Effect,” Economic Journal 110 (465), July.

Honohan, Patrick (2004). Financial Sector Policy and the Poor: Selected Findings and Issues. World Bank Working Paper No. 43. Washington, DC: World Bank.

Karlan, Dean and Zinman, Jonathan (2005). “Observing Unobservables: Identifying Information Asymmetries with a Consumer Credit Field Experiment,” Princeton University, Woodrow Wilson School, draft.

Laffont, Jean-Jacques and Patrick Rey (2003). "Collusion and Group Lending with Moral Hazard,” draft, IDEI, Toulouse and University of Southern California.

Microbanking Bulletin (2005). “Trend Lines,” Issue 10, No. 5, March.

Rai, Ashok and Tomas Sjöström (2004). "Is Grameen lending effcient? Repayment incentives and insurance in village economies," Review of Economic Studies 71 (1), January: 217-34.

Robinson, Marguerite (2001). The Microfinance Revolution: Sustainable Banking for the Poor. Washington, DC: The World Bank.

Stiglitz, Joseph (1990). “Peer Monitoring and Credit Markets” World Bank Economic Review 4 (3). 351-366. 
Stiglitz, Joseph, and Andrew Weiss (1981). "Credit Markets in Credit with Imperfect Information”, American Economic Review 71: 393 - 410. 


\begin{tabular}{|c|c|c|c|c|c|c|}
\hline Table 1: Variable Name & Definition & Mean & St. Dev. & Median & Minimum & Maximum \\
\hline Financial Self-Suffiency & $\begin{array}{l}\text { Adjusted operating revenue / Adjusted (financial } \\
\text { expense + loan loss provision expense + operating } \\
\text { expense) }\end{array}$ & 1.035 & 0.340 & 1.016 & 0.146 & 2.183 \\
\hline Operational Self-Suffiency & $\begin{array}{l}\text { Operating revenue / (Financial expense + loan loss } \\
\text { provision expense }+ \text { operating expense) }\end{array}$ & 1.165 & 0.413 & 1.115 & 0.157 & 3.872 \\
\hline Return on Assets adjusted & $\begin{array}{l}\text { Adjusted net operating income after taxes / Average } \\
\text { total assets }\end{array}$ & -0.027 & 0.183 & 0.002 & -1.541 & 0.280 \\
\hline Average Loan Size to GNP per capita & & 0.676 & 0.836 & 0.376 & 0.025 & 5.831 \\
\hline Age & Age of the MFI in years & 9.300 & 7.011 & 8 & 2 & 40 \\
\hline Size of MFI Indicator & $\begin{array}{l}\text { Size of the loan portfolio, which is } 1 \text { for small, } 2 \text { for } \\
\text { medium and } 3 \text { for large. }\end{array}$ & 2.025 & 0.710 & 2 & 1 & 3 \\
\hline For-Profit Status & For-profit is 1 , non-profit is 0. & 0.237 & 0.427 & 0 & 0 & 1 \\
\hline Village Bank Lender & $\begin{array}{l}\text { The MFI does village bank style lending (as opposed } \\
\text { to MFI who do individual lending or solidarity } \\
\text { lending). }\end{array}$ & 0.165 & 0.373 & 0 & 0 & 1 \\
\hline Solidarity Lender & $\begin{array}{l}\text { The MFI does some solidarity style lending (as } \\
\text { opposed to MFI who do only individual lending or } \\
\text { do village bank lending. }\end{array}$ & 0.397 & 0.491 & 0 & 0 & 1 \\
\hline Real Gross Portfolio Yield & $\begin{array}{l}\text { (Yield on gross portfolio (nominal) - Inflation rate) / } \\
(1+\text { Inflation rate) }\end{array}$ & 0.348 & 0.191 & 0.297 & 0.051 & 0.976 \\
\hline Capital Costs to Assets & $\begin{array}{l}\text { (Rent }+ \text { transportion }+ \text { depreciation }+ \text { office }+ \text { other }) \\
/ \text { total assets }\end{array}$ & 18.381 & 84.939 & 0.190 & 0 & 816.339 \\
\hline Labor Costs to Assets & Personnel expenses/total assets & 18.553 & 81.284 & 0.225 & 0 & 747.121 \\
\hline Loans to Assets & Gross loan portfolio/total assets & 0.689 & 0.186 & 0.726 & 0.077 & 0.987 \\
\hline Donations to Loan Portfolio & Donations for financial services/gross loan portfolio & 0.122 & 0.342 & 0.005 & 0 & 2.081 \\
\hline $\begin{array}{l}\text { Average Loan Size to GNP per capita of } \\
\text { the poorest } 20 \%\end{array}$ & & 2.983 & 3.939 & 1.324 & 0.108 & 19.511 \\
\hline Average Loan Size & In US dollars. & 715.698 & 934.582 & 360.500 & 36.000 & 5131.231 \\
\hline Women Borrowers & Percentage of borrowers who are women. & 0.649 & 0.263 & 0.615 & 0.150 & 1 \\
\hline Portfolio Risk & Loan Portfolio at risk at 30 days. & 0.033 & 0.044 & 0.016 & 0 & 0.223 \\
\hline Eastern Europe and Central Asia & & 0.169 & 0.377 & 0 & 0 & 1 \\
\hline Africa & & 0.169 & 0.377 & 0 & 0 & 1 \\
\hline Latin America and the Caribbean & & 0.403 & 0.493 & 0 & 0 & 1 \\
\hline Middle East and North Africa & & 0.073 & 0.260 & 0 & 0 & 1 \\
\hline South Asia & & 0.097 & 0.297 & 0 & 0 & 1 \\
\hline East Asia and the Pacific & & 0.089 & 0.285 & 0 & 0 & 1 \\
\hline
\end{tabular}


Table 2: Correlations

\begin{tabular}{|c|c|c|c|c|c|c|c|c|c|c|c|c|c|c|c|}
\hline & $\begin{array}{l}\text { Financial } \\
\text { Self- } \\
\text { Suffiency }\end{array}$ & $\begin{array}{l}\text { Operation } \\
\text { al Self- } \\
\text { Suffiency }\end{array}$ & $\begin{array}{l}\text { Return on } \\
\text { Assets } \\
\text { adjusted }\end{array}$ & $\begin{array}{l}\text { Average } \\
\text { Loan Size } \\
\text { to GNPPC }\end{array}$ & Age & $\begin{array}{l}\text { Size of } \\
\text { MFI }\end{array}$ & $\begin{array}{l}\text { For- } \\
\text { Profit } \\
\text { Status }\end{array}$ & $\begin{array}{l}\text { Village } \\
\text { Bank } \\
\text { Lender }\end{array}$ & $\begin{array}{l}\text { Solidarity } \\
\text { Lender }\end{array}$ & $\begin{array}{l}\text { Real Gross } \\
\text { Portfolio } \\
\text { Yield }\end{array}$ & $\begin{array}{l}\text { Capital } \\
\text { Costs to } \\
\text { Assets }\end{array}$ & $\begin{array}{l}\text { Labor } \\
\text { Costs to } \\
\text { Assets }\end{array}$ & $\begin{array}{l}\text { Loans to } \\
\text { Assets }\end{array}$ & $\begin{array}{l}\text { Donations } \\
\text { to Loan } \\
\text { Portfolio }\end{array}$ & $\begin{array}{l}\text { ALS to } \\
\text { GNPPC of } \\
\text { the } \\
\text { poorest }\end{array}$ \\
\hline Operational & $0.8963 *$ & 1 & & & & & & & & & & & & & \\
\hline Self-Suffiency & 124 & 124 & & & & & & & & & & & & & \\
\hline Return on Assets & $0.7005^{*}$ & $0.5943^{*}$ & 1 & & & & & & & & & & & & \\
\hline (adjusted) & 123 & 123 & 123 & & & & & & & & & & & & \\
\hline \multirow[t]{2}{*}{ ALS to GNPPC } & 0.0726 & 0.0828 & 0.1174 & 1 & & & & & & & & & & & \\
\hline & 117 & 117 & 117 & 117 & & & & & & & & & & & \\
\hline \multirow[t]{2}{*}{ Age } & $0.2517 *$ & $0.1858 *$ & $0.1899 *$ & 0.1521 & 1 & & & & & & & & & & \\
\hline & 120 & 120 & 119 & 113 & 120 & & & & & & & & & & \\
\hline \multirow[t]{2}{*}{ Size } & $0.3655^{*}$ & $0.2962 *$ & $0.3517^{*}$ & $0.3408^{*}$ & $0.2285^{*}$ & 1 & & & & & & & & & \\
\hline & 122 & 122 & 121 & 115 & 118 & 122 & & & & & & & & & \\
\hline \multirow[t]{2}{*}{ For-Profit Status } & 0.0678 & -0.0141 & 0.0929 & $0.2073 *$ & -0.0427 & $0.2664 *$ & 1 & & & & & & & & \\
\hline & 118 & 118 & 118 & 112 & 114 & 117 & 118 & & & & & & & & \\
\hline \multirow[t]{2}{*}{ Village Bank } & -0.1119 & -0.0738 & -0.1323 & $-0.2594 *$ & -0.1568 & $-0.2744^{*}$ & $-0.2487 *$ & 1 & & & & & & & \\
\hline & 121 & 121 & 120 & 114 & 117 & 120 & 117 & 121 & & & & & & & \\
\hline \multirow[t]{2}{*}{ Solidarity Lender } & -0.1162 & -0.0926 & -0.0886 & -0.1374 & -0.0917 & -0.038 & 0.0575 & $-0.3608 *$ & 1 & & & & & & \\
\hline & 121 & 121 & 120 & 114 & 117 & 120 & 117 & 121 & 121 & & & & & & \\
\hline \multirow[t]{2}{*}{ Portfolio Yield } & -0.0543 & -0.1484 & -0.0383 & $-0.4004 *$ & $-0.2305^{*}$ & ${ }^{*}-0.2808^{*}$ & * -0.0458 & $0.4185^{*}$ & -0.1129 & 1 & & & & & \\
\hline & 122 & 122 & 122 & 116 & 118 & 120 & 117 & 119 & 119 & 122 & & & & & \\
\hline \multirow[t]{2}{*}{ Capital Costs to Assets } & -0.0975 & -0.0659 & -0.0411 & -0.0731 & -0.0411 & -0.022 & -0.0007 & 0.0275 & 0.1502 & $0.1971^{*}$ & 1 & & & & \\
\hline & 124 & 124 & 123 & 117 & 120 & 122 & 118 & 121 & 121 & 122 & 124 & & & & \\
\hline \multirow[t]{2}{*}{ Labor Costs to Assets } & -0.1098 & -0.0713 & -0.0471 & -0.0751 & -0.0301 & -0.029 & 0.0125 & 0.0167 & $0.1799 *$ & 0.1678 & $0.9753^{*}$ & 1 & & & \\
\hline & 124 & 124 & 123 & 117 & 120 & 122 & 118 & 121 & 121 & 122 & 124 & 124 & & & \\
\hline \multirow[t]{2}{*}{ Loans to Assets } & $0.2758 *$ & 0.1383 & $0.2648 *$ & 0.1701 & 0.0161 & $0.3284^{*}$ & 0.0267 & $-0.2011 *$ & 0.1067 & $-0.2732 *$ & 0.0263 & 0.0061 & 1 & & \\
\hline & 124 & 124 & 123 & 117 & 120 & 122 & 118 & 121 & 121 & 122 & 124 & 124 & 124 & & \\
\hline \multirow[t]{2}{*}{ Donations to Loans } & $-0.4768 *$ & $-0.4382 *$ & $-0.6707^{*}$ & $-0.2052 *$ & $-0.2001^{*}$ & ${ }^{*}-0.4045^{*}$ & -0.178 & $0.2294 *$ & 0.1023 & $0.2304^{*}$ & 0.0021 & 0.0007 & $-0.4439 *$ & 1 & \\
\hline & 124 & 124 & 123 & 117 & 120 & 122 & 118 & 121 & 121 & 122 & 124 & 124 & 124 & 124 & \\
\hline \multicolumn{16}{|l|}{ ALS to GNPPC of the } \\
\hline poorest 20\% & $\begin{array}{l}0.0012 \\
102\end{array}$ & $\begin{array}{l}-0.0077 \\
102\end{array}$ & $\begin{array}{l}0.0891 \\
102\end{array}$ & $\begin{array}{l}0.8653^{*} \\
99\end{array}$ & $\begin{array}{l}0.3922^{*} \\
98\end{array}$ & $\begin{array}{l}0.3098^{*} \\
100\end{array}$ & $\begin{array}{l}0.0768 \\
97\end{array}$ & $\begin{array}{l}-0.2508^{*} \\
99\end{array}$ & $\begin{array}{l}-0.2632 * \\
99\end{array}$ & $\begin{array}{l}-0.4471 * \\
102\end{array}$ & $\begin{array}{l}-0.0781 \\
102\end{array}$ & $\begin{array}{l}-0.0814 \\
102\end{array}$ & $\begin{array}{l}0.1157 \\
102\end{array}$ & $\begin{array}{l}-0.1682 \\
102\end{array}$ & $\begin{array}{l}1 \\
102\end{array}$ \\
\hline Women Borrowers & -0.1765 & $-0.2277^{*}$ & $-0.2092 *$ & $-0.3567 *$ & -0.1124 & $-0.3404^{*}$ & $-0.2563 *$ & $0.3760 *$ & $0.3259 *$ & $0.2901^{*}$ & 0.0646 & 0.0876 & -0.0091 & $0.2873 *$ & $-0.3778 *$ \\
\hline & 114 & 114 & 114 & 108 & 110 & 112 & 109 & 111 & 111 & 113 & 114 & 114 & 114 & 114 & 94 \\
\hline
\end{tabular}


Table 3: MFI Lending Style by Region

\begin{tabular}{|l|rrr|r|}
\hline & Individual & Solidarity & Village Bank & Total \\
\hline \hline East Asia and Pacific & 7 & 4 & 0 & 11 \\
Eastern Europe and Central Asia & 8 & 11 & 2 & 21 \\
Latin America & 32 & 10 & 8 & 50 \\
Middle East and North Africa & 3 & 3 & 3 & 9 \\
South Asia & 1 & 9 & 2 & 12 \\
Sub-Saharan Africa & 5 & 11 & 5 & 21 \\
\hline Total & 56 & 48 & 20 & 124 \\
\hline
\end{tabular}


Table 4: Summary Statistics by Lending Type

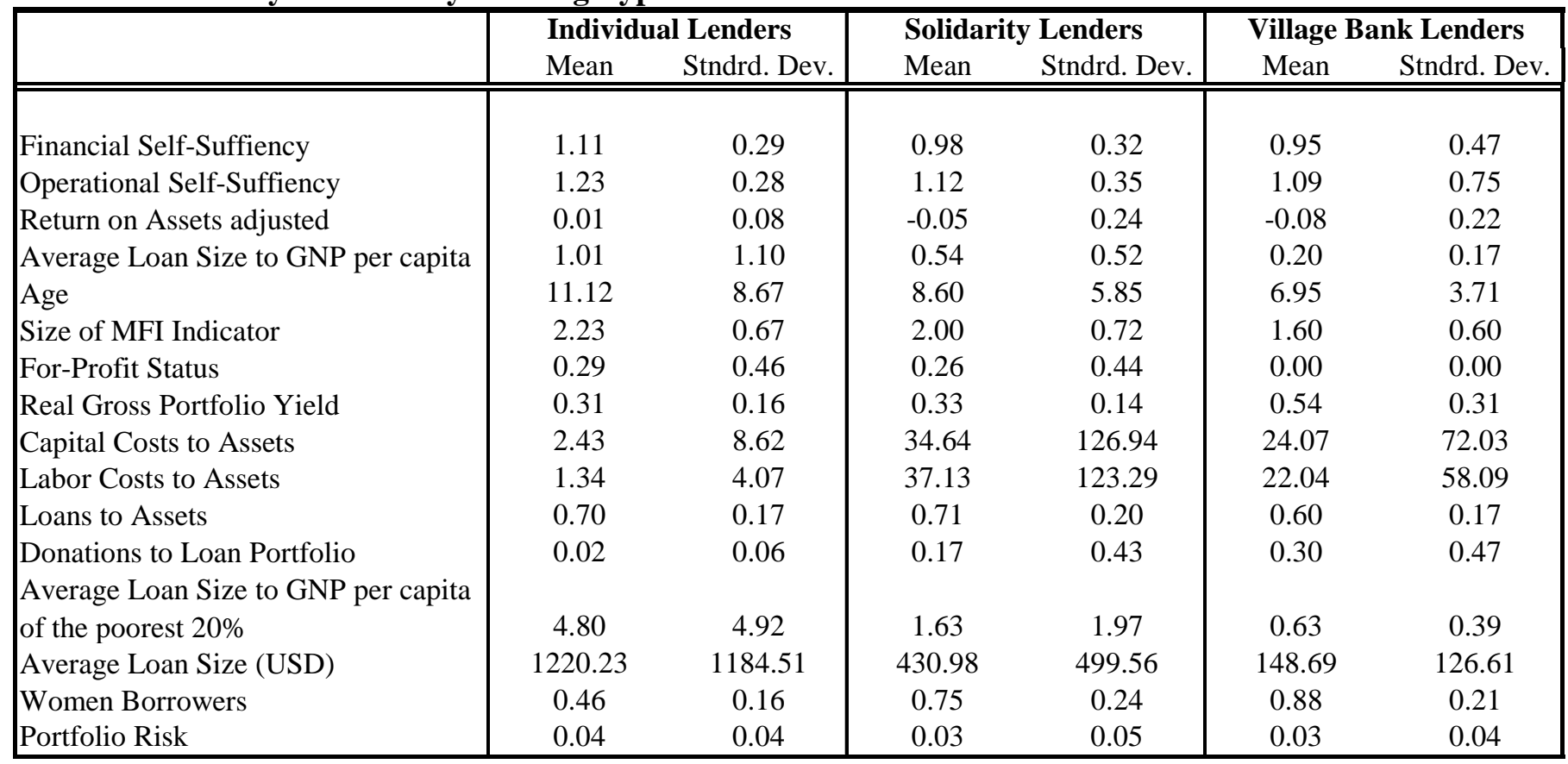


Table 5: Subsidized Share of Funding

\begin{tabular}{|l|c|c|}
\hline & Mean & $\begin{array}{c}\text { Standard } \\
\text { deviation }\end{array}$ \\
\hline Sample average & $21.4 \%$ & $29.3 \%$ \\
\hline By Lending Type & & \\
Individual-Based (n=56) & 11.0 & 17.9 \\
Solidarity Group (n=48) & 27.7 & 37.3 \\
Village Banks (n=20) & 35.5 & 23.6 \\
\hline By Profit Status & & \\
For-profit (n=28) & & \\
Not-for-profit (n=90) & 6.6 & 14.9 \\
\hline \hline
\end{tabular}

Notes: Subsidized Share of Funding is equal to (subsidized costs of funds adjustment+ in-kind subsidy adjustment + donated equity)/(total liabilities+ total equity). "Profit status" refers to the institution's official designation and is independent of actual profitability.

Table 6: Correlations of Subsidized Share of Funding

\begin{tabular}{|c|c|c|c|c|c|c|c|}
\hline & \multicolumn{3}{|c|}{ "Correlations with: } & \multirow{2}{*}{$\begin{array}{c}\text { Capital } \\
\text { costs/ } \\
\text { Assets } \\
\end{array}$} & \multirow{2}{*}{$\begin{array}{l}\text { Labor } \\
\text { Costs/ } \\
\text { Assets } \\
\end{array}$} & \multirow{2}{*}{$\begin{array}{c}\text { Port- } \\
\text { folio at } \\
\text { Risk }\end{array}$} & \multirow{2}{*}{$\begin{array}{c}\text { For- } \\
\text { Profit } \\
\text { Dummy }\end{array}$} \\
\hline & FSS & OSS & ROA & & & & \\
\hline Sample average & $-.28 * *$ & -.17 & $-.53^{* * *}$ & .10 & .13 & -.08 & $-.28 * *$ \\
\hline \multicolumn{8}{|l|}{ By lending type: } \\
\hline Individual-based & -.19 & .02 & .14 & .14 & .12 & -.21 & $-.25^{*}$ \\
\hline Solidarity Group & $-.45^{* * *}$ & $-.45^{* * *}$ & $-.73 * * *$ & $.25 *$ & .08 & -.02 & $-.28 *$ \\
\hline Village Bank & .22 & .27 & .10 & -.01 & .13 & .03 & -- \\
\hline
\end{tabular}

Notes: Subsidized Share of Funding is equal to (subsidized costs of funds adjustment+ in-kind subsidy adjustment + donated equity)/(total liabilities+ total equity). FSS is financial self-sufficiency, OSS is operational self-sufficiency, and portfolio at risk is the share of loans delinquent at least thirty days. There is no variation in profit status for village banks, and thus no correlation can be calculated for that variable and our subsidy measures for that group. 
Table 7: Profitability Regressions

\begin{tabular}{|c|c|c|c|c|c|c|c|c|c|}
\hline & Financi & al Self-Su & fficiency & Operatic & nal Self-S & ufficiency & & turn on Ass & sets \\
\hline & -1 & -2 & -3 & -4 & -5 & -6 & 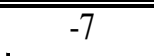 & -8 & -9 \\
\hline Real Yield & 0.55 & 0.607 & 0.735 & 0.367 & 0.383 & 0.663 & 0.307 & 0.336 & 0.319 \\
\hline & {$[2.92] * * *$} & {$[3.68]^{* * *}$} & {$[3.63]^{* * *}$} & {$[1.73]^{*}$} & {$[1.94]^{*}$} & {$[2.81]^{* * *}$} & {$[2.57]^{* *}$} & {$[2.67]^{* * *}$} & {$[2.93]^{* * *}$} \\
\hline Real Yield (Villagebank) & -0.675 & -0.742 & -0.867 & -1.124 & -1.143 & -1.428 & -0.281 & -0.316 & -0.29 \\
\hline & {$[1.40]$} & {$[1.45]$} & [1.59] & {$[1.26]$} & [1.29] & {$[1.52]$} & {$[1.89]^{*}$} & {$[2.05]^{* *}$} & {$[2.05]^{* *}$} \\
\hline Real Yield (Solidarity) & -0.153 & -0.011 & -0.236 & -0.155 & -0.115 & -0.558 & -0.271 & -0.198 & -0.218 \\
\hline & {$[0.32]$} & {$[0.02]$} & {$[0.41]$} & {$[0.30]$} & {$[0.23]$} & {$[0.89]$} & {$[1.02]$} & {$[0.78]$} & {$[0.81]$} \\
\hline Capital Costs to Assets & -0.017 & -0.017 & -0.018 & -0.012 & -0.012 & -0.013 & -0.006 & -0.006 & -0.006 \\
\hline & {$[4.81]^{* * *}$} & {$[6.24]^{* * *}$} & {$[7.03]^{* * *}$} & {$[5.10]^{* * *}$} & {$[5.25]^{* * *}$} & {$[6.20]^{* * *}$} & {$[2.41]^{* *}$} & {$[3.04]^{* * *}$} & {$[3.16]^{* * *}$} \\
\hline Capital Costs to Assets (Villagebank) & -0.049 & -0.058 & -0.057 & -0.089 & -0.091 & -0.091 & -0.027 & -0.031 & -0.03 \\
\hline & {$[1.84]^{*}$} & {$[2.03]^{* *}$} & {$[1.99]^{* *}$} & {$[1.65]$} & {$[1.77]^{*}$} & {$[1.77]^{*}$} & {$[1.58]$} & {$[1.79]^{*}$} & {$[1.67]^{*}$} \\
\hline Capital Costs to Assets (Solidarity) & 0.02 & 0.019 & 0.022 & 0.012 & 0.012 & 0.015 & 0.007 & 0.007 & 0.009 \\
\hline & {$[5.26]^{* * *}$} & {$[6.50]^{* * *}$} & {$[6.05]^{* * *}$} & {$[5.03]^{* * *}$} & {$[5.02]^{* * *}$} & {$[3.85]^{* * *}$} & {$[2.81]^{* * *}$} & {$[3.31]^{* * *}$} & {$[3.44]^{* * *}$} \\
\hline Labor Costs to Assets & 0.037 & 0.034 & 0.037 & 0.032 & 0.032 & 0.038 & 0.008 & 0.006 & 0.007 \\
\hline & {$[6.77]^{* * *}$} & {$[6.31]^{* * *}$} & {$[6.71]^{* * *}$} & {$[4.95]^{* * *}$} & {$[4.76]^{* * *}$} & {$[5.21]^{* * *}$} & {$[1.92]^{*}$} & {$[1.66]$} & {$[1.81]^{*}$} \\
\hline Labor Costs to Assets (Villagebank) & 0.001 & 0.009 & 0.006 & 0.025 & 0.027 & 0.022 & 0.012 & 0.016 & 0.015 \\
\hline & {$[0.07]$} & {$[0.53]$} & {$[0.34]$} & {$[0.77]$} & {$[0.90]$} & {$[0.74]$} & {$[1.10]$} & [1.43] & {$[1.28]$} \\
\hline Labor Costs to Assets (Solidarity) & -0.04 & -0.036 & -0.04 & -0.033 & -0.032 & -0.039 & -0.009 & -0.007 & -0.009 \\
\hline & {$[7.40]^{* * *}$} & {$[6.79]^{* * *}$} & {$[6.68]^{* * *}$} & {$[5.28]^{* * *}$} & {$[4.88]^{* * *}$} & {$[4.87]^{* * *}$} & {$[2.41]^{* *}$} & {$[2.09]^{* *}$} & {$[2.56]^{* *}$} \\
\hline Village bank & 0.345 & 0.376 & 0.407 & 0.677 & 0.686 & 0.758 & 0.099 & 0.115 & 0.105 \\
\hline & [1.03] & [1.03] & {$[1.08]$} & {$[1.05]$} & [1.06] & {$[1.15]$} & {$[1.25]$} & [1.39] & {$[1.35]$} \\
\hline Solidarity & -0.025 & -0.113 & -0.041 & -0.074 & -0.098 & 0.05 & 0.04 & -0.004 & -0.002 \\
\hline & {$[0.15]$} & {$[0.68]$} & {$[0.21]$} & {$[0.40]$} & {$[0.56]$} & {$[0.24]$} & {$[0.62]$} & {$[0.07]$} & {$[0.02]$} \\
\hline Size Indicator & 0.212 & 0.178 & 0.19 & 0.211 & 0.201 & 0.23 & 0.081 & 0.063 & 0.059 \\
\hline & {$[4.50]^{* * *}$} & {$[3.84]^{* * *}$} & {$[3.73]^{* * *}$} & {$[3.76]^{* * *}$} & {$[3.10]^{* * *}$} & {$[3.23]^{* * *}$} & {$[3.11]^{* * *}$} & {$[2.74]^{* * *}$} & {$[2.64]^{* * *}$} \\
\hline Log of age & 0.144 & 0.149 & 0.142 & 0.157 & 0.159 & 0.138 & 0.082 & 0.085 & 0.091 \\
\hline & {$[2.92]^{* * *}$} & {$[3.20]^{* * *}$} & {$[2.79]^{* * *}$} & {$[2.30] * *$} & {$[2.37]^{* *}$} & {$[2.00]^{* *}$} & {$[1.76]^{*}$} & {$[1.81]^{*}$} & {$[1.70]^{*}$} \\
\hline Average Loan Size to GNP per capita & -0.016 & -0.018 & -0.009 & -0.026 & -0.026 & -0.008 & 0.01 & 0.009 & 0.008 \\
\hline & {$[0.46]$} & {$[0.56]$} & {$[0.29]$} & {$[0.53]$} & {$[0.55]$} & {$[0.19]$} & {$[0.72]$} & {$[0.70]$} & {$[0.62]$} \\
\hline Loans to assets ratio & & 0.448 & 0.421 & & 0.127 & 0.081 & & 0.23 & 0.223 \\
\hline & & {$[2.43]^{* *}$} & {$[2.29]^{* *}$} & & [0.39] & {$[0.25]$} & & {$[2.63]^{* *}$} & {$[2.48]^{* *}$} \\
\hline For-p rofit dummy & & & -0.082 & & & -0.178 & & & 0.007 \\
\hline & & & {$[0.96]$} & & & {$[1.83]^{*}$} & & & {$[0.19]$} \\
\hline E. Eur. and Ctrl Asia & 0.238 & 0.205 & 0.193 & 0.428 & 0.418 & 0.384 & 0.144 & 0.127 & 0.136 \\
\hline & {$[2.50]^{* *}$} & {$[2.12]^{* *}$} & {$[1.89]^{*}$} & {$[3.35]^{* * *}$} & {$[2.92]^{* * *}$} & {$[2.65]^{* * *}$} & {$[1.52]$} & {$[1.45]$} & [1.39] \\
\hline Sub. Africa & 0.084 & 0.119 & 0.119 & 0.164 & 0.173 & 0.191 & 0.04 & 0.058 & 0.042 \\
\hline & {$[0.90]$} & [1.29] & [1.15] & {$[1.32]$} & {$[1.50]$} & [1.53] & {$[0.46]$} & {$[0.64]$} & {$[0.48]$} \\
\hline Middle East and N. Africa & 0.083 & 0.115 & 0.104 & 0.102 & 0.111 & 0.08 & 0.103 & 0.12 & 0.126 \\
\hline & {$[0.76]$} & {$[1.17]$} & [1.03] & {$[0.71]$} & {$[0.76]$} & {$[0.54]$} & [1.38] & {$[1.55]$} & {$[1.49]$} \\
\hline South Asia & 0.281 & 0.323 & 0.327 & 0.465 & 0.477 & 0.481 & 0.094 & 0.116 & 0.118 \\
\hline & {$[1.88]^{*}$} & {$[2.23]^{* *}$} & {$[2.25]^{* *}$} & {$[1.85]^{*}$} & {$[2.01]^{* *}$} & {$[2.04]^{* *}$} & {$[1.10]$} & {$[1.30]$} & {$[1.30]$} \\
\hline East Asia & -0.059 & -0.046 & -0.028 & -0.025 & -0.022 & 0.031 & -0.003 & 0.003 & 0 \\
\hline & {$[1.00]$} & {$[0.86]$} & {$[0.43]$} & {$[0.41]$} & {$[0.37]$} & {$[0.41]$} & {$[0.08]$} & {$[0.08]$} & {$[0.01]$} \\
\hline Constant & 0.075 & -0.175 & -0.195 & 0.19 & 0.12 & 0.074 & -0.491 & -0.619 & -0.616 \\
\hline & [0.43] & [1.12] & [1.24] & {$[0.80]$} & {$[0.62]$} & {$[0.38]$} & {$[2.51]^{* *}$} & {$[2.68]^{* * *}$} & {$[2.73]^{* * *}$} \\
\hline Observations & 107 & 107 & 104 & 107 & 107 & 104 & 107 & 107 & 104 \\
\hline R-squared & 0.46 & 0.5 & 0.51 & 0.4 & 0.4 & 0.42 & 0.31 & 0.35 & 0.36 \\
\hline
\end{tabular}

All models estimated via OLS, with White's Heteroskedasticity consistent standard errors

* significant at $10 \%$; ** significant at $5 \%$; ** significant at $1 \%$ 
Table 8: Profitability Regressions - Yield side

\begin{tabular}{|c|c|c|c|c|c|c|c|c|c|}
\hline \multirow{2}{*}{ 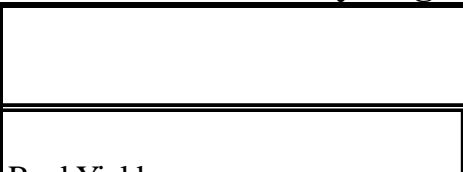 } & \multicolumn{3}{|c|}{$\begin{array}{c}\text { Financial } \\
\text { Self-Sufficiency }\end{array}$} & \multicolumn{3}{|c|}{$\begin{array}{c}\text { Operational } \\
\text { Self-Sufficiency }\end{array}$} & \multicolumn{3}{|c|}{ Return on Assets } \\
\hline & -1 & -2 & -3 & -4 & -5 & -6 & -7 & -8 & -9 \\
\hline & 2.072 & 1.925 & 1.888 & 1.978 & 1.975 & 1.962 & 0.582 & 0.501 & 0.515 \\
\hline & {$[3.40]^{* * *}$} & {$[3.20] * * *$} & {$[3.08] * * *$} & {$[2.87] * * *$} & {$[2.56]^{* *}$} & {$[2.52]^{* *}$} & {$[2.36]^{* *}$} & {$[2.11]^{* *}$} & {$[2.07]^{* *}$} \\
\hline \multirow[t]{2}{*}{ Real Yield squared } & -1.778 & -1.488 & -1.38 & -1.82 & -1.804 & -1.609 & -0.345 & -0.189 & -0.215 \\
\hline & {$[2.66] * * *$} & {$[2.25] * *$} & {$[2.02] * *$} & {$[2.51]^{* *}$} & {$[2.07] * *$} & {$[1.83]^{*}$} & {$[1.46]$} & {$[0.87]$} & {$[0.91]$} \\
\hline \multirow[t]{2}{*}{ Real Yield (Villagebank) } & -1.612 & -1.514 & -1.492 & -3.233 & -3.062 & -3.211 & -0.338 & -0.357 & -0.294 \\
\hline & {$[0.98]$} & {$[0.88]$} & {$[0.79]$} & {$[1.03]$} & [1.03] & [0.98] & {$[0.63]$} & {$[0.61]$} & {$[0.50]$} \\
\hline \multirow[t]{2}{*}{ Real Yield (Villagebank) squared } & 1.496 & 1.287 & 1.184 & 2.802 & 2.593 & 2.586 & 0.276 & 0.248 & 0.185 \\
\hline & {$[1.03]$} & {$[0.87]$} & {$[0.71]$} & {$[1.08]$} & {$[1.07]$} & [0.93] & {$[0.53]$} & {$[0.44]$} & [0.33] \\
\hline \multirow[t]{2}{*}{ Real Yield (Solidarity) } & -4.925 & -4.803 & -4.948 & -5.067 & -5.108 & -5.502 & -2.809 & -2.722 & -2.798 \\
\hline & {$[2.98] * * *$} & {$[3.10]^{* * *}$} & {$[3.19]^{* * *}$} & {$[2.87] * * *$} & {$[2.84]^{* * *}$} & {$[2.88]^{* * *}$} & {$[2.06]^{* *}$} & {$[2.06] * *$} & {$[2.04]^{* *}$} \\
\hline \multirow[t]{2}{*}{ Real Yield (Solidarity) squared } & 6.113 & 6.108 & 6.277 & 6.283 & 6.359 & 6.615 & 3.288 & 3.253 & 3.367 \\
\hline & {$[3.04] * * *$} & {$[3.28] * * *$} & {$[3.47] * * *$} & {$[2.97] * * *$} & {$[3.02]^{* * *}$} & {$[3.06]^{* * *}$} & {$[2.14]^{* *}$} & {$[2.17]^{* *}$} & {$[2.15]^{* *}$} \\
\hline \multirow[t]{2}{*}{ Capital Costs to Assets } & 0.001 & 0 & -0.002 & 0 & 0 & 0 & 0 & 0 & -0.001 \\
\hline & {$[0.55]$} & {$[0.20]$} & {$[0.47]$} & {$[0.33]$} & {$[0.01]$} & {$[0.16]$} & {$[0.33]$} & [0.59] & [0.33] \\
\hline \multirow[t]{2}{*}{ Labor Costs to Assets } & -0.001 & -0.001 & 0 & 0 & 0 & 0 & 0 & 0 & 0.001 \\
\hline & {$[0.70]$} & {$[0.45]$} & {$[0.18]$} & {$[0.30]$} & {$[0.01]$} & {$[0.01]$} & {$[0.37]$} & {$[0.57]$} & {$[0.42]$} \\
\hline \multirow[t]{2}{*}{ Village bank } & 0.317 & 0.307 & 0.297 & 0.753 & 0.73 & 0.737 & 0.016 & 0.021 & 0.011 \\
\hline & {$[0.71]$} & {$[0.63]$} & {$[0.59]$} & {$[0.85]$} & {$[0.84]$} & {$[0.81]$} & {$[0.14]$} & {$[0.16]$} & {$[0.08]$} \\
\hline \multirow[t]{2}{*}{ Solidarity } & 0.752 & 0.691 & 0.71 & 0.749 & 0.751 & 0.834 & 0.46 & 0.426 & 0.435 \\
\hline & {$[2.40]^{* *}$} & {$[2.33]^{* *}$} & {$[2.35]^{* *}$} & {$[2.29]^{* *}$} & {$[2.19]^{* *}$} & {$[2.27]^{* *}$} & {$[2.11]^{* *}$} & {$[2.07]^{* *}$} & {$[2.04] * *$} \\
\hline \multirow[t]{2}{*}{ Size Indicator } & 0.202 & 0.171 & 0.184 & 0.193 & 0.188 & 0.216 & 0.077 & 0.061 & 0.061 \\
\hline & {$[4.25]^{* * *}$} & {$[3.61]^{* * *}$} & {$[3.61]^{* * *}$} & {$[3.49] * * *$} & {$[2.91]^{* * *}$} & {$[3.08] * * *$} & {$[3.32]^{* * *}$} & {$[2.87] * * *$} & {$[2.74]^{* * *}$} \\
\hline \multirow[t]{2}{*}{ Log of age } & 0.182 & 0.186 & 0.174 & 0.204 & 0.206 & 0.185 & 0.1 & 0.101 & 0.103 \\
\hline & {$[3.33]^{* * *}$} & {$[3.47]^{* * *}$} & {$[3.10]^{* * *}$} & {$[2.53]^{* *}$} & {$[2.59]^{* *}$} & {$[2.31]^{* *}$} & {$[1.90]^{*}$} & {$[1.92]^{*}$} & {$[1.81]^{*}$} \\
\hline \multirow[t]{2}{*}{ Loans to assets ratio } & & 0.41 & 0.409 & & 0.049 & 0.029 & & 0.209 & 0.21 \\
\hline & & {$[1.84]^{*}$} & {$[1.81]^{*}$} & & {$[0.13]$} & {$[0.07]$} & & {$[2.32]^{* *}$} & {$[2.32]^{* *}$} \\
\hline \multirow[t]{2}{*}{ For-profit dummy } & & & -0.05 & & & -0.126 & & & -0.002 \\
\hline & & & {$[0.69]$} & & & [1.49] & & & {$[0.06]$} \\
\hline \multirow[t]{2}{*}{ E. Eur. and Ctrl Asia } & 0.209 & 0.169 & 0.159 & 0.37 & 0.367 & 0.342 & 0.128 & 0.107 & 0.109 \\
\hline & {$[2.15]^{* *}$} & [1.61] & {$[1.51]$} & {$[3.12] * * *$} & {$[2.51]^{* *}$} & {$[2.37]^{* *}$} & {$[1.47]$} & [1.32] & [1.29] \\
\hline \multirow[t]{2}{*}{ Sub. Africa } & 0.052 & 0.07 & 0.104 & 0.095 & 0.091 & 0.135 & 0.013 & 0.025 & 0.025 \\
\hline & {$[0.50]$} & {$[0.73]$} & {$[0.97]$} & {$[0.81]$} & {$[0.79]$} & {$[1.05]$} & {$[0.16]$} & [0.33] & [0.33] \\
\hline \multirow[t]{2}{*}{ Middle East and N. Africa } & 0.143 & 0.181 & 0.169 & 0.184 & 0.189 & 0.164 & 0.134 & 0.153 & 0.155 \\
\hline & {$[1.57]$} & {$[2.31]^{* *}$} & {$[2.11]^{* *}$} & {$[1.65]$} & {$[1.67]^{*}$} & [1.47] & {$[1.65]$} & {$[1.84]^{*}$} & {$[1.76]^{*}$} \\
\hline \multirow[t]{2}{*}{ South Asia } & 0.256 & 0.288 & 0.295 & 0.399 & 0.403 & 0.415 & 0.083 & 0.099 & 0.101 \\
\hline & {$[1.69]^{*}$} & {$[1.95]^{*}$} & {$[1.97]^{*}$} & {$[1.66]^{*}$} & {$[1.77]^{*}$} & {$[1.82]^{*}$} & {$[0.92]$} & [1.05] & [1.05] \\
\hline East Asia & -0.054 & -0.041 & -0.068 & -0.047 & -0.041 & -0.033 & 0.015 & 0.019 & 0.007 \\
\hline & {$[0.75]$} & {$[0.63]$} & {$[1.06]$} & {$[0.66]$} & {$[0.58]$} & {$[0.44]$} & {$[0.28]$} & [0.38] & [0.13] \\
\hline Constant & -0.238 & -0.448 & -0.432 & -0.15 & -0.178 & -0.158 & -0.555 & -0.661 & -0.666 \\
\hline & {$[1.10]$} & {$[2.40] * *$} & {$[2.33] * *$} & {$[0.49]$} & [0.83] & {$[0.74]$} & {$[2.69] * * *$} & {$[2.82] * * *$} & {$[2.74] * * *$} \\
\hline Observations & 113 & 114 & 110 & 113 & 114 & 110 & 113 & 114 & 110 \\
\hline R-squared & 0.38 & 0.42 & 0.43 & 0.32 & 0.32 & 0.33 & 0.3 & 0.33 & 0.33 \\
\hline
\end{tabular}

All models estimated via OLS, with White's Heteroskedasticity consistent standard errors

* significant at $10 \%$; ** significant at $5 \%$; *** significant at $1 \%$ 
Table 9: Portfolio At Risk Regressions

\begin{tabular}{|c|c|c|c|}
\hline & \multicolumn{3}{|c|}{ Portfolio at Risk } \\
\hline & -1 & -2 & -3 \\
\hline \multirow[t]{2}{*}{ Real Yield } & 0.199 & 0.21 & 0.221 \\
\hline & {$[1.51]$} & {$[1.77]^{*}$} & {$[1.91]^{*}$} \\
\hline \multirow[t]{2}{*}{ Real Yield squared } & -0.177 & -0.22 & -0.271 \\
\hline & {$[1.15]$} & {$[1.57]$} & {$[2.19]^{* *}$} \\
\hline \multirow[t]{2}{*}{ Real Yield (Villagebank) } & -0.123 & -0.123 & -0.102 \\
\hline & {$[0.64]$} & {$[0.67]$} & {$[0.56]$} \\
\hline \multirow[t]{2}{*}{ Real Yield (Villagebank) squared } & 0.096 & 0.12 & 0.136 \\
\hline & {$[0.47]$} & {$[0.61]$} & {$[0.74]$} \\
\hline \multirow[t]{2}{*}{ Real Yield (Solidarity) } & -0.397 & -0.41 & -0.399 \\
\hline & {$[1.70]^{*}$} & {$[1.88]^{*}$} & {$[1.83]^{*}$} \\
\hline \multirow[t]{2}{*}{ Real Yield (Solidarity) squared } & 0.335 & 0.331 & 0.356 \\
\hline & {$[1.23]$} & [1.30] & [1.44] \\
\hline \multirow[t]{2}{*}{ Capital Costs to Assets } & 0.019 & 0.016 & 0.013 \\
\hline & {$[0.58]$} & {$[0.50]$} & {$[0.42]$} \\
\hline \multirow[t]{2}{*}{ Labor Costs to Assets } & 0.086 & 0.094 & 0.09 \\
\hline & {$[1.94]^{*}$} & {$[2.26]^{* *}$} & {$[2.15] * *$} \\
\hline \multirow[t]{2}{*}{ Village bank } & -0.016 & -0.011 & -0.015 \\
\hline & {$[1.55]$} & {$[1.22]$} & {$[1.61]$} \\
\hline \multirow[t]{2}{*}{ Solidarity } & 0.012 & 0.011 & 0.016 \\
\hline & {$[1.23]$} & [1.17] & {$[1.71]^{*}$} \\
\hline \multirow[t]{2}{*}{ Size Indicator } & 0 & 0 & 0 \\
\hline & {$[0.19]$} & {$[0.27]$} & {$[0.79]$} \\
\hline \multirow[t]{2}{*}{ Log of age } & 0 & 0 & 0 \\
\hline & {$[0.14]$} & {$[0.21]$} & {$[0.51]$} \\
\hline \multirow[t]{2}{*}{ Loans to assets ratio } & & -0.077 & -0.071 \\
\hline & & {$[2.27]^{* *}$} & {$[2.11]^{* *}$} \\
\hline \multirow[t]{2}{*}{ For-profit dummy } & & & 0.011 \\
\hline & & & {$[1.03]$} \\
\hline \multirow[t]{2}{*}{ E. Eur. and Ctrl Asia } & -0.021 & -0.015 & -0.01 \\
\hline & {$[1.83]^{*}$} & {$[1.14]$} & {$[0.73]$} \\
\hline \multirow[t]{2}{*}{ Sub. Africa } & -0.008 & -0.013 & -0.015 \\
\hline & {$[0.55]$} & [0.83] & {$[0.93]$} \\
\hline \multirow[t]{2}{*}{ Middle East and N. Africa } & 0 & -0.008 & -0.003 \\
\hline & {$[0.02]$} & {$[0.42]$} & {$[0.16]$} \\
\hline \multirow[t]{2}{*}{ South Asia } & -0.023 & -0.029 & -0.029 \\
\hline & {$[1.57]$} & {$[2.07]^{* *}$} & {$[2.12]^{* *}$} \\
\hline \multirow[t]{2}{*}{ East Asia } & -0.016 & -0.019 & -0.012 \\
\hline & {$[0.90]$} & {$[0.90]$} & {$[0.55]$} \\
\hline \multirow[t]{2}{*}{ Constant } & 0.014 & 0.059 & 0.05 \\
\hline & {$[0.46]$} & [1.64] & [1.42] \\
\hline Observations & 111 & 111 & 108 \\
\hline R-squared & 0.15 & 0.22 & 0.23 \\
\hline
\end{tabular}

Estimated via OLS, with White's Heteroskedasticity consistent standard error

* significant at $10 \%$; ** significant at $5 \%$; *** significant at $1 \%$ 
Table 10: Cost/Loan Size Trade-offs

\begin{tabular}{|c|c|c|c|c|}
\hline & \multicolumn{2}{|c|}{ White's Standard Errors } & \multicolumn{2}{|c|}{ Robust Regressions } \\
\hline \multirow[t]{2}{*}{ Loan Size Indicator } & $\begin{array}{l}-1 \\
-0.215\end{array}$ & $\begin{array}{l}-2 \\
-0.238\end{array}$ & $\begin{array}{l}-3 \\
-0.17\end{array}$ & $\begin{array}{l}-2 \\
-0.1\end{array}$ \\
\hline & {$[2.55]^{* *}$} & {$[3.08]^{* * *}$} & {$[2.11]^{* *}$} & {$[2.18]^{* *}$} \\
\hline Loan Size Indicator squared & 0.054 & 0.065 & 0.04 & \\
\hline \multirow[t]{2}{*}{ Loan Size*Village bank } & $\begin{array}{r}{[1.93]^{*}} \\
-0.036\end{array}$ & $\begin{array}{r}{[2.61]^{* *}} \\
-0.17\end{array}$ & $\left.\right|^{[1.76]^{*}} 5.4$ & ${ }^{[1.81]^{*}}$ \\
\hline & {$[0.03]$} & {$[0.16]$} & {$[3.80]^{* * *}$} & {$[4.20]^{* * *}$} \\
\hline Loan Size squared*Village bank & {$[0.05]^{-0.079}$} & $[0.40]]^{0.483}$ & $\begin{array}{c}-12.96 \\
{[3.83]^{* * *}}\end{array}$ & $\begin{array}{r}-12.67 \\
{[4.06]^{* * *}}\end{array}$ \\
\hline Loan Size*Solidarity & $\begin{array}{c}-0.755 \\
{[3.36]^{* * *}}\end{array}$ & $\begin{array}{r}-0.505 \\
{[2.82]^{* * *}}\end{array}$ & $\begin{array}{c}-0.5 \\
{[3.35]^{* * *}}\end{array}$ & $\begin{array}{r}-0.5 \\
{[3.49]^{* * *}}\end{array}$ \\
\hline Loan Size squared*Solidarity & $\begin{array}{c}0.341 \\
{[3.36]^{* * *}}\end{array}$ & $\begin{array}{c}0.215 \\
{[2.68]^{* * *}}\end{array}$ & $\begin{array}{c}0.24 \\
{[2.77]^{* * *}}\end{array}$ & $\begin{array}{r}0.2 \\
{[2.86]^{* * *}}\end{array}$ \\
\hline Village bank dummy & {$[1.02]$} & {$[0.52]{ }^{0.076}$} & {$[1.53]^{-0.20}$} & $\frac{-0.2 \varepsilon}{[2.34]^{* *}}$ \\
\hline Solidarity dummy & $\begin{array}{c}0.252 \\
{[2.48]^{* *}}\end{array}$ & $\frac{0.159}{[2.11]^{* *}}$ & $\begin{array}{r}0.21 \\
{[2.90]^{* * *}}\end{array}$ & $\begin{array}{r}0.2 \\
{[3.22]^{* * *}}\end{array}$ \\
\hline Size indicator & $\begin{array}{c}-0.116 \\
{[2.75]^{* * *}}\end{array}$ & {$[1.15]^{-0.033}$} & {$[1.62]^{-0.04}$} & {$[1.32]^{-0.0}$} \\
\hline Age & ${ }^{-0.128}{ }^{-0.61]^{* *}}$ & $\begin{array}{c}-0.136 \\
{[3.84]^{* * *}}\end{array}$ & {$[4.75]^{* * *}$} & $\frac{-0.12}{[4.78]^{* * *}}$ \\
\hline Donations over Loan Portfolio & & $\begin{array}{c}0.507 \\
{[6.61]^{* * *}}\end{array}$ & & $\begin{array}{r}0.42 \\
{[8.48]^{* * *}}\end{array}$ \\
\hline E. Eur. and Ctrl Asia & {$[0.33]^{-0.032}$} & {$[1.55]^{-0.1}$} & {$[1.54]^{-0.08}$} & {$[2.38]^{* *}$} \\
\hline Sub. A & {$[1.59]^{0.127}$} & {$[1.50]^{0.094}$} & {$[1.74]^{*}$} & {$[1.98]^{0.0}$} \\
\hline Middle East and N. Africa & {$[1.31]^{-0.156}$} & $\begin{array}{c}-0.229 \\
{[2.98]^{* * *}}\end{array}$ & $\begin{array}{r}-0.23 \\
{[3.78]^{* * *}}\end{array}$ & $\begin{array}{r}-0.22 \\
{[4.14]^{* * *}}\end{array}$ \\
\hline South Asia & $c^{-0.18}$ & $\frac{-0.202}{[3.03]^{* * *}}$ & $\begin{array}{c}-0.19 \\
{[3.17]^{* * *}}\end{array}$ & $\begin{array}{c}-0.20 \\
{[3.68]^{* * *}}\end{array}$ \\
\hline East Asia & {$[0.47]$} & $[0.84]]^{0.043}$ & {$[0.60]$} & {$[0.70] \quad 0.04$} \\
\hline Constant & $\begin{array}{c}0.91 € \\
{[7.57]^{* * *}}\end{array}$ & $\begin{array}{c}0.764 \\
{[7.37]^{* * *}}\end{array}$ & $\begin{array}{c}0.76 \\
{[9.04]^{* * *}}\end{array}$ & $\begin{array}{r}0.69 \\
{[8.92]^{* * *}}\end{array}$ \\
\hline $\begin{array}{l}\text { bservatio } \\
\text { l-squared }\end{array}$ & $\begin{array}{l}108 \\
0.5\end{array}$ & $\begin{array}{r}108 \\
0.75\end{array}$ & $\begin{array}{r}11 \\
0.6\end{array}$ & $\begin{array}{l}11 \\
0.8\end{array}$ \\
\hline
\end{tabular}

Dependent Variable: Cost per dollar lent (Total Expenses over Loan Portfolio)

* significant at $10 \%$; ** significant at $5 \%$; $* * *$ significant at $1 \%$

t-statistics in parentheses 
Table 11: Mission Drift

\begin{tabular}{|c|c|c|c|c|c|c|c|c|c|}
\hline & \multicolumn{3}{|c|}{ Average Loan Size over GNP } & \multicolumn{3}{|c|}{ ALS over GNPPC poorest $20 \%$} & \multicolumn{3}{|c|}{ Women Borrowers } \\
\hline & $\overline{-1}$ & $\overline{-2}$ & -3 & -4 & $\overline{-5}$ & -6 & -7 & -8 & -9 \\
\hline \multirow[t]{2}{*}{ Financial Self-Sufficiency } & -0.004 & -0.515 & -1.618 & -0.212 & -2.22 & -6.457 & -0.023 & 0.044 & 0.27 \\
\hline & {$[0.03]$} & [1.61] & {$[2.44]^{* *}$} & {$[0.27]$} & [0.94] & 7] & {$[0.27]$} & {$[0.43]$} & [2.13]** \\
\hline \multirow[t]{2}{*}{ Village bank } & -0.883 & -1.572 & -0.917 & -4.197 & -7.014 & -3.953 & 0.413 & 0.667 & 0.623 \\
\hline & {$[4.22] * * *$} & {$[3.60] * * *$} & {$[1.72]^{*}$} & {$[5.10] * * *$} & {$[2.49]^{* *}$} & & {$[6.12]^{* * *}$} & {$[3.94]^{* * *}[$} & {$[3.67]^{* * *}$} \\
\hline \multirow[t]{2}{*}{ Solidarity } & -0.593 & -1.474 & -1.143 & -2.838 & -6.344 & -5.096 & 0.28 & 0.261 & 0.458 \\
\hline & {$[2.30]^{* *}$} & {$[2.96]^{* * *}$} & {$[1.96]^{*}$} & {$[3.32]^{* * *}$} & {$[2.15]^{* *}$} & $3]^{*}$ & {$[6.10]^{* * *}$} & [1.55] & {$[2.63]^{* *}$} \\
\hline \multirow[t]{2}{*}{ Self-Sufficiency*Village } & & 0.649 & 1.876 & & 2.645 & 7.331 & & -0.267 & -0.355 \\
\hline & & {$[1.88]^{*}$} & {$[2.68] * * *$} & & [1.09] & & & {$[1.44]$} & {$[2.08]^{* *}$} \\
\hline \multirow[t]{2}{*}{ Self-Sufficiency*Solidarity } & & 0.841 & 1.586 & & 3.321 & 5.985 & & 0.029 & -0.033 \\
\hline & & {$[2.02]^{* *}$} & {$[2.26]^{* *}$} & & [1.26] & & & {$[0.19]$} & {$[0.19]$} \\
\hline \multirow[t]{2}{*}{ Age } & & & 0.043 & & & 0.245 & & & -0.001 \\
\hline & & & [1.50] & & & $5]^{* *}$ & & & [0.59] \\
\hline \multirow[t]{2}{*}{ Age*Village bank } & & & -0.075 & & & -0.365 & & & -0.026 \\
\hline & & & {$[1.98]^{*}$} & & & $4]^{* *}$ & & & [1.44] \\
\hline \multirow[t]{2}{*}{ Age*Solidarity } & & & -0.064 & & & -0.284 & & & 0.007 \\
\hline & & & [2.09]** & & & 7]** & & & [1.55] \\
\hline \multirow[t]{2}{*}{ Size Indicator } & & & 0.624 & & & 2.155 & & & -0.113 \\
\hline & & & {$[1.72]^{*}$} & & & & & & {$[2.31]^{* *}$} \\
\hline \multirow[t]{2}{*}{ Size*Village bank } & & & -0.556 & & & -1.949 & & & 0.176 \\
\hline & & & {$[1.60]$} & & & 3] & & & {$[1.74]^{*}$} \\
\hline \multirow[t]{2}{*}{ Size*Solidarity } & & & -0.203 & & & -0.523 & & & -0.102 \\
\hline & & & [0.57] & & & 30] & & & [1.48] \\
\hline \multirow[t]{2}{*}{ E. Eur. and Ctrl Asia } & 0.254 & 0.189 & 0.3 & -1.538 & -1.674 & -0.141 & -0.082 & -0.09 & -0.096 \\
\hline & {$[1.35]$} & [0.93] & [1.26] & {$[1.70]^{*}$} & [1.64] & & [1.31] & {$[1.40]$} & [1.58] \\
\hline \multirow[t]{2}{*}{ Sub. Africa } & 0.234 & 0.26 & 0.418 & -1.45 & -1.347 & 0.161 & -0.029 & -0.038 & -0.05 \\
\hline & {$[1.28]$} & [1.43] & {$[2.13]^{* *}$} & {$[1.63]$} & [1.52] & & {$[0.48]$} & {$[0.64]$} & {$[0.85]$} \\
\hline \multirow[t]{2}{*}{ Middle East and N. Africa } & -0.312 & -0.293 & -0.189 & -3.17 & -3.202 & -2.155 & -0.023 & -0.014 & -0.033 \\
\hline & {$[1.91]^{*}$} & {$[1.84]^{*}$} & [1.00] & {$[3.57]^{* * *}$} & {$[3.71]^{* * *}$} & $4]^{* *}$ & {$[0.38]$} & {$[0.20]$} & {$[0.50]$} \\
\hline \multirow[t]{2}{*}{ South Asia } & 0.332 & 0.304 & 0.49 & -1.138 & -1.27 & 0.117 & 0.058 & 0.06 & 0.027 \\
\hline & {$[0.62]$} & {$[0.56]$} & [0.93] & {$[0.88]$} & {$[0.96]$} & & {$[0.60]$} & {$[0.68]$} & [0.30] \\
\hline \multirow[t]{2}{*}{ East Asia } & -0.276 & -0.232 & -0.066 & -3.093 & -2.922 & -1.915 & 0.021 & 0.011 & 0.075 \\
\hline & {$[1.46]$} & [1.37] & [0.34] & {$[3.54]^{* * * *}$} & {$[3.59] * * *$} & $4]^{*}$ & {$[0.34]$} & [0.17] & [1.07] \\
\hline Constant & $\begin{array}{r}1.019 \\
{[4.00] * * *}\end{array}$ & $\begin{array}{l}1.578 \\
{[3.63]^{* * *}}\end{array}$ & $\begin{array}{r}0.832 \\
{[1.58]}\end{array}$ & $\begin{array}{r}6.007 \\
{[4.52]^{* * *}}\end{array}$ & $\begin{array}{r}8.213 \\
{[2.81]^{* * *}}\end{array}$ & 4.534 & $\begin{array}{c}0.497 \\
{[5.03]^{* * *}}\end{array}$ & $\begin{array}{r}0.425 \\
{[3.75]^{* * *}}\end{array}$ & $\begin{array}{r}0.447 \\
{[3.65]^{* * *}}\end{array}$ \\
\hline Obser & 113 & 113 & 108 & 99 & 99 & 94 & 110 & 110 & 105 \\
\hline R-squared & 0.18 & 0.2 & 0.35 & 0.28 & 0.29 & 0.45 & 0.41 & 0.44 & 0.6 \\
\hline
\end{tabular}

All models estimated via OLS, with White's Heteroskedasticity consistent standard errors

* significant at $10 \%$; $* *$ significant at $5 \%$; ${ }^{* * *}$ significant at $1 \%$ 
Table 12: Summary of Mission Drift Results

\begin{tabular}{|c|c|c|}
\hline & $\begin{array}{l}\text { Association with Size of } \\
\text { Loans } \\
\text { (significance) }\end{array}$ & $\begin{array}{c}\text { Association with } \\
\text { Proportion of Loans to } \\
\text { Women (significance) }\end{array}$ \\
\hline \multicolumn{3}{|l|}{$\begin{array}{l}\text { Individual-Based Lenders } \\
\text { Increases in: }\end{array}$} \\
\hline $\begin{array}{l}\text { Age of firm } \\
\text { Size of firm } \\
\text { Financial Self-Sufficiency }\end{array}$ & $\begin{array}{l}\text { Larger (5\%) } \\
\text { Larger (10\%) } \\
\text { Smaller (5\%) }\end{array}$ & $\begin{array}{c}\text { No significant relation } \\
\text { Lower (5\%) } \\
\text { Higher (5\%) }\end{array}$ \\
\hline \multicolumn{3}{|l|}{$\begin{array}{l}\text { Solidarity Group Lenders } \\
\text { Increases in: }\end{array}$} \\
\hline $\begin{array}{l}\text { Age of firm } \\
\text { Size of firm } \\
\text { Financial Self-Sufficiency }\end{array}$ & $\begin{array}{l}\text { No significant relation } \\
\text { Larger (1\%) } \\
\text { No significant relation }\end{array}$ & $\begin{array}{c}\text { No significant relation } \\
\text { Lower (1\%) } \\
\text { Higher (5\%) }\end{array}$ \\
\hline \multicolumn{3}{|l|}{$\begin{array}{l}\text { Village Banks } \\
\text { Increases in: }\end{array}$} \\
\hline $\begin{array}{l}\text { Age of firm } \\
\text { Size of firm } \\
\text { Financial Self-Sufficiency }\end{array}$ & $\begin{array}{l}\text { No significant relation } \\
\text { No significant relation } \\
\text { No significant relation }\end{array}$ & $\begin{array}{l}\text { No significant relation } \\
\text { No significant relation } \\
\text { No significant relation }\end{array}$ \\
\hline
\end{tabular}

Notes: Significance levels in brackets. Results refer to models 3,6, and 9 in Table 11. A significant result for loan size implies that the coefficient was significant in either model 3 (with dependent variable average loan size over GNP per capita) or model 6 (with dependent variable average loan size over the GNP per capita of the poorest $20 \%$ of the population), or both. 
Appendix A. Financial Statement Adjustments and their Effects

\begin{tabular}{|c|c|c|}
\hline Adjustment & Effect on Financial Statements & $\begin{array}{l}\text { Type of Institution Most Affected by } \\
\text { Adjustment }\end{array}$ \\
\hline $\begin{array}{l}\text { Inflation Adjustment } \\
\text { of Equity (minus Net } \\
\text { Fixed Assets) }\end{array}$ & $\begin{array}{l}\text { Increases financial expense accounts on } \\
\text { income statement, to some degree offset } \\
\text { by inflation income account for } \\
\text { revaluation of fixed assets. Generates a } \\
\text { reserve in the balance sheet's equity } \\
\text { account, reflecting that portion of the } \\
\text { MFI's retained earnings that has been } \\
\text { consumed by the effects of inflation. } \\
\text { Decreases profitability and "real” retained } \\
\text { earnings. }\end{array}$ & $\begin{array}{l}\text { MFIs funded more by equity than by } \\
\text { liabilities will be hardest hit, } \\
\text { especially in high-inflation } \\
\text { countries. }\end{array}$ \\
\hline $\begin{array}{l}\text { Reclassification of } \\
\text { certain long-term } \\
\text { liabilities into equity, } \\
\text { and subsequent } \\
\text { inflation adjustment }\end{array}$ & $\begin{array}{l}\text { Decreases concessionary loan account and } \\
\text { increases equity account; increases } \\
\text { inflation adjustment on income statement } \\
\text { and balance sheet. }\end{array}$ & $\begin{array}{l}\text { NGOs that have long-term low- } \\
\text { interest "loans" from international } \\
\text { agencies that function more as } \\
\text { donations than loans. }\end{array}$ \\
\hline $\begin{array}{l}\text { Subsidized cost of } \\
\text { funds adjustment. }\end{array}$ & $\begin{array}{l}\text { Increases financial expense on income } \\
\text { statement to the extent that the MFI's } \\
\text { liabilities carry a below-market rate of } \\
\text { interest. Decreases net income and } \\
\text { increases subsidy adjustment account on } \\
\text { balance sheet. }\end{array}$ & $\begin{array}{l}\text { MFIs with heavily subsidized loans } \\
\text { (i.e., large lines of credit from } \\
\text { governments or international } \\
\text { agencies at highly subsidized rates). }\end{array}$ \\
\hline $\begin{array}{l}\text { Subsidy adjustment: } \\
\text { current-year cash } \\
\text { donations to cover } \\
\text { operating expenses }\end{array}$ & $\begin{array}{l}\text { Reduces operating expense on income } \\
\text { statement (if the MFI records donations as } \\
\text { operating income). Increases subsidy } \\
\text { adjustment account on balance sheet. }\end{array}$ & $\begin{array}{l}\text { NGOs during their start-up phase. } \\
\text { The adjustment is relatively less } \\
\text { important for mature institutions. }\end{array}$ \\
\hline $\begin{array}{l}\text { In-kind subsidy } \\
\text { adjustment (e.g. } \\
\text { donation of goods or } \\
\text { services: line staff } \\
\text { paid for by technical } \\
\text { assistance providers) }\end{array}$ & $\begin{array}{l}\text { Increases operating expense on income } \\
\text { statement to the extent that the MFI is } \\
\text { receiving subsidized or donated goods or } \\
\text { services. Decreases net income, increases } \\
\text { subsidy adjustment on balance sheet. }\end{array}$ & $\begin{array}{l}\text { MFIs using goods or services for } \\
\text { which they are not paying a market- } \\
\text { based cost (i.e., MFIs during their } \\
\text { start-up phase). }\end{array}$ \\
\hline $\begin{array}{l}\text { Loan loss reserve and } \\
\text { provision expense } \\
\text { adjustment }\end{array}$ & $\begin{array}{l}\text { Usually increases loan loss provision } \\
\text { expense on income statement and loan } \\
\text { loss reserve on balance sheet. }\end{array}$ & $\begin{array}{l}\text { MFIs that have unrealistic loan loss } \\
\text { provisioning policies. }\end{array}$ \\
\hline Write-off adjustment & $\begin{array}{l}\text { On balance sheet, reduces gross loan } \\
\text { portfolio and loan loss reserve by an equal } \\
\text { amount, so that neither the net loan } \\
\text { portfolio nor the income statement is } \\
\text { affected. Improves (lowers) portfolio-at - } \\
\text { risk ratio. }\end{array}$ & $\begin{array}{l}\text { MFIs that do not write off non- } \\
\text { performing loans aggressively } \\
\text { enough. }\end{array}$ \\
\hline $\begin{array}{l}\text { Reversal of interest } \\
\text { income accrued on } \\
\text { non-performing loans }\end{array}$ & $\begin{array}{l}\text { Reduces financial income and net profit } \\
\text { on the income statement, and equity on } \\
\text { the balance sheet. }\end{array}$ & $\begin{array}{l}\text { MFIs that continue accruing income } \\
\text { on delinquent loans past the point } \\
\text { where collection becomes unlikely, } \\
\text { or that fail to reverse previously } \\
\text { accrued income on such loans. }\end{array}$ \\
\hline
\end{tabular}

Source: The Microbanking Bulletin, Our Methodology (www.mixmbb.org/en/company/our_methodology.html) 
Appendix B Table 1: Profitability Regressions

\begin{tabular}{|c|c|c|c|c|c|c|c|c|c|}
\hline & & $\begin{array}{l}\text { Financial } \\
\text { If-Sufficie }\end{array}$ & & & $\begin{array}{l}\text { Operationa } \\
\text { If-Sufficie }\end{array}$ & & Ret & urn on Ass & sets \\
\hline & -1 & -2 & -3 & -4 & -5 & -6 & -7 & -8 & -9 \\
\hline Real Yield & 0.552 & 0.587 & 0.719 & 0.312 & 0.338 & 0.62 & 0.137 & 0.157 & 0.205 \\
\hline & {$[1.77]^{*}$} & {$[2.04] * *$} & {$[2.24] * *$} & {$[1.04]$} & [1.09] & {$[1.82]^{*}$} & {$[1.87]^{*}$} & {$[2.29] * *$} & {$[2.75]^{* * *}$} \\
\hline Real Yield (Villagebank) & -0.217 & -0.098 & -0.192 & 0.189 & 0.145 & -0.138 & -0.113 & -0.187 & -0.257 \\
\hline & {$[0.56]$} & {$[0.27]$} & {$[0.50]$} & {$[0.51]$} & {$[0.38]$} & [0.34] & {$[1.25]$} & {$[2.20]^{* *}$} & {$[2.85]^{* * *}$} \\
\hline Real Yield (Solidarity) & -0.391 & -0.304 & -0.638 & -0.127 & -0.157 & -0.937 & -0.027 & -0.058 & -0.171 \\
\hline & {$[0.91]$} & {$[0.77]$} & {$[1.42]$} & {$[0.31]$} & [0.37] & {$[1.96]^{*}$} & {$[0.27]$} & {$[0.62]$} & [1.63] \\
\hline Capital Costs to Assets & -0.017 & -0.017 & -0.018 & -0.014 & -0.013 & -0.013 & -0.007 & -0.007 & -0.007 \\
\hline & {$[2.66]^{* * *}$} & {$[2.93]^{* * *}$} & {$[2.98]^{* * *}$} & {$[2.26]^{* *}$} & {$[2.06]^{* *}$} & {$[2.11]^{* *}$} & {$[5.02] * * *$} & {$[4.86]^{* * *}$} & {$[4.91]^{* * *}$} \\
\hline Capital Costs to Assets (Villagebank) & -0.027 & -0.038 & -0.037 & -0.028 & -0.04 & -0.044 & -0.049 & -0.055 & -0.056 \\
\hline & {$[0.80]$} & {$[1.22]$} & [1.17] & {$[0.88]$} & [1.19] & [1.31] & {$[8.90]^{* * *}$} & {$[10.53]^{* * *}$} & {$[10.80]^{* * *}$} \\
\hline Capital Costs to Assets (Solidarity) & 0.019 & 0.018 & 0.021 & 0.014 & 0.012 & 0.014 & 0.008 & 0.007 & 0.008 \\
\hline & {$[2.90]^{* * *}$} & {$[2.98]^{* * *}$} & {$[3.01]^{* * *}$} & {$[2.18]^{* *}$} & {$[1.84]^{*}$} & {$[1.81]^{*}$} & {$[5.40] * * *$} & {$[5.03] * * *$} & {$[4.75]^{* * *}$} \\
\hline Labor Costs to Assets & 0.039 & 0.034 & 0.038 & 0.041 & 0.036 & 0.039 & 0.008 & 0.006 & 0.007 \\
\hline & {$[2.88]^{* * *}$} & {$[2.74] * * *$} & {$[2.93]^{* * *}$} & {$[3.15]^{* * *}$} & {$[2.64] * * *$} & {$[2.84] * * *$} & {$[2.60]^{* *}$} & {$[2.13]^{* *}$} & {$[2.43]^{* *}$} \\
\hline Labor Costs to Assets (Villagebank) & -0.009 & 0.003 & 0 & -0.006 & 0.005 & 0.004 & 0.025 & 0.03 & 0.029 \\
\hline & {$[0.31]$} & [0.12] & {$[0.01]$} & {$[0.23]$} & {$[0.18]$} & {$[0.14]$} & {$[5.46]^{* * *}$} & {$[6.87]^{* * *}$} & {$[6.73] * * *$} \\
\hline Labor Costs to Assets (Solidarity) & -0.042 & -0.036 & -0.041 & -0.041 & -0.035 & -0.039 & -0.009 & -0.007 & -0.008 \\
\hline & {$[3.08]^{* * *}$} & {$[2.85]^{* * *}$} & {$[3.05]^{* * *}$} & {$[3.16]^{* * *}$} & {$[2.56]^{* *}$} & {$[2.71] * * *$} & {$[2.96]^{* * *}$} & {$[2.38]^{* *}$} & {$[2.68] * * *$} \\
\hline Village bank & -0.003 & -0.11 & -0.106 & -0.282 & -0.288 & -0.21 & 0.026 & 0.068 & 0.096 \\
\hline & {$[0.02]$} & {$[0.60]$} & {$[0.55]$} & {$[1.48]$} & [1.45] & [1.04] & {$[0.57]$} & [1.55] & {$[2.16]^{* *}$} \\
\hline Solidarity & 0.095 & -0.016 & 0.092 & 0.005 & -0.056 & 0.191 & 0.016 & 0.002 & 0.037 \\
\hline & {$[0.59]$} & {$[0.11]$} & {$[0.55]$} & {$[0.03]$} & {$[0.34]$} & [1.07] & {$[0.43]$} & {$[0.04]$} & {$[0.95]$} \\
\hline Size Indicator & 0.197 & 0.158 & 0.172 & 0.152 & 0.153 & 0.195 & 0.03 & 0.026 & 0.03 \\
\hline & {$[4.24] * * *$} & {$[3.59] * * *$} & {$[3.64] * * *$} & {$[3.40]^{* * *}$} & {$[3.20] * * *$} & {$[3.89]^{* * *}$} & {$[2.72] * * *$} & {$[2.44] * *$} & {$[2.76] * * *$} \\
\hline Log of age & 0.153 & 0.137 & 0.134 & 0.087 & 0.078 & 0.067 & 0.044 & 0.042 & 0.039 \\
\hline & {$[2.99]^{* * *}$} & {$[2.92]^{* * *}$} & {$[2.69]^{* * *}$} & {$[1.79]^{*}$} & [1.53] & [1.27] & {$[3.68]^{* * *}$} & {$[3.80] * * *$} & {$[3.38] * * *$} \\
\hline Average Loan Size to GNP per capita & -0.008 & -0.021 & -0.013 & 0.004 & -0.01 & 0.001 & 0 & -0.003 & 0 \\
\hline & {$[0.20]$} & {$[0.57]$} & {$[0.34]$} & {$[0.11]$} & {$[0.26]$} & {$[0.02]$} & {$[0.02]$} & {$[0.32]$} & {$[0.01]$} \\
\hline Loans to assets ratio & & 0.6 & 0.561 & & 0.415 & 0.369 & & 0.147 & 0.14 \\
\hline & & {$[4.02]^{* * *}$} & {$[3.64]^{* * *}$} & & {$[2.57]^{* *}$} & {$[2.27]^{* *}$} & & {$[4.13]^{* * *}$} & {$[3.91]^{* * *}$} \\
\hline For-profit dummy & & & -0.092 & & & -0.174 & & & -0.031 \\
\hline & & & {$[1.16]$} & & & {$[2.08]^{* *}$} & & & {$[1.66]^{*}$} \\
\hline E. Eur. and Ctrl Asia & 0.168 & 0.107 & 0.09 & 0.323 & 0.254 & 0.2 & 0.042 & 0.016 & 0.003 \\
\hline & {$[1.76]^{*}$} & {$[1.21]$} & {$[0.98]$} & {$[3.55]^{* * *}$} & {$[2.66]^{* * *}$} & {$[2.05]^{* *}$} & {$[1.89]^{*}$} & {$[0.76]$} & {$[0.15]$} \\
\hline Sub. Africa & 0.028 & 0.083 & 0.079 & -0.009 & 0.047 & 0.084 & 0.017 & 0.034 & 0.032 \\
\hline & {$[0.31]$} & [0.98] & {$[0.87]$} & {$[0.10]$} & {$[0.51]$} & {$[0.87]$} & {$[0.83]$} & {$[1.70]^{*}$} & {$[1.53]$} \\
\hline Middle East and N. Africa & 0.178 & 0.194 & 0.192 & 0.25 & 0.216 & 0.201 & 0.045 & 0.039 & 0.03 \\
\hline & {$[1.65]$} & {$[1.96]^{*}$} & {$[1.87]^{*}$} & {$[2.43]^{* *}$} & {$[2.02]^{* *}$} & {$[1.85]^{*}$} & {$[1.78]^{*}$} & {$[1.66]$} & [1.27] \\
\hline South Asia & 0.123 & 0.235 & 0.259 & 0.049 & 0.141 & 0.208 & 0.042 & 0.062 & 0.061 \\
\hline & {$[1.22]$} & {$[2.52]^{* *}$} & {$[2.72] * * *$} & {$[0.51]$} & [1.40] & {$[2.06]^{* *}$} & {$[1.79]^{*}$} & {$[2.81]^{* * *}$} & {$[2.78] * * *$} \\
\hline East Asia & -0.075 & -0.042 & -0.005 & -0.05 & -0.029 & 0.04 & -0.022 & -0.015 & -0.006 \\
\hline & {$[0.62]$} & [0.38] & {$[0.04]$} & {$[0.43]$} & {$[0.24]$} & [0.29] & {$[0.79]$} & {$[0.56]$} & {$[0.21]$} \\
\hline Constant & 0.078 & -0.194 & -0.221 & 0.475 & 0.234 & 0.137 & -0.21 & -0.298 & -0.304 \\
\hline & {$[0.39]$} & [0.96] & [1.07] & {$[2.47] * *$} & [1.07] & {$[0.62]$} & {$[4.51] * * *$} & {$[6.21]^{* * *}$} & {$[6.34] * * *$} \\
\hline Observations & 106 & 106 & 103 & 106 & 106 & 103 & 107 & 107 & 104 \\
\hline R-squared & 0.46 & 0.56 & 0.57 & 0.46 & 0.48 & 0.53 & 0.75 & 0.78 & 0.8 \\
\hline
\end{tabular}

All regressions estimated via Robust Regression in STATA.

* significant at $10 \%$;* significant at $5 \%$; *** significant at $1 \%$ 
Appendix B Table 2: Mission Drift

\begin{tabular}{|c|c|c|c|c|c|c|c|c|c|}
\hline & \multicolumn{3}{|c|}{ Average Loan Size over GNP } & \multicolumn{3}{|c|}{ ALS over GNPPC poorest $20 \%$} & \multicolumn{3}{|c|}{ Women Borrowers } \\
\hline \multirow{3}{*}{ Financial Self-Sufficiency } & $\overline{-1}$ & $\overline{-2}$ & $\overline{-3}$ & $\overline{-4}$ & -5 & $\overline{-6}$ & $\overline{-7}$ & $\overline{-8}$ & $\overline{-9}$ \\
\hline & 0.069 & -0.424 & -0.684 & 0.099 & -1.12 & -10.084 & 0.04 & 0.032 & 0.298 \\
\hline & {$[0.63]$} & {$[2.26]^{* *}$} & {$[2.36]^{* *}$} & {$[0.26]$} & {$[1.72]^{*}$} & {$[11.61]^{* * *}$} & {$[0.67]$} & [0.31] & {$[2.58]^{* *}$} \\
\hline \multirow[t]{2}{*}{ Village bank } & -0.458 & -1.057 & -0.48 & -1.422 & -3.07 & -4.448 & 0.472 & 0.398 & 0.502 \\
\hline & {$[4.16]^{* * *}$} & {$[3.67]^{* * *}$} & {$[1.20]$} & {$[3.78] * * *$} & {$[3.04]^{* * *}$} & {$[3.53]^{* * *}$} & {$[7.58] * * *$} & {$[2.43]^{* *}$} & {$[2.84] * * *$} \\
\hline \multirow[t]{2}{*}{ Solidarity } & -0.309 & -0.984 & -0.564 & -0.82 & -2.667 & -5.148 & 0.276 & 0.303 & 0.611 \\
\hline & {$[3.43]^{* * *}$} & {$[3.48]^{* * *}$} & [1.50] & {$[2.76] * * *$} & {$[2.66]^{* * *}$} & {$[4.25]^{* * *}$} & {$[5.83]^{* * *}$} & {$[1.93]^{*}$} & {$[3.95]^{* * *}$} \\
\hline \multirow[t]{2}{*}{ Self-Sufficiency*Village } & & 0.585 & 0.964 & & 1.509 & 11.027 & & 0.085 & -0.195 \\
\hline & & {$[2.22] * *$} & {$[2.28]^{* *}$} & & {$[1.68]^{*}$} & {$[8.53]^{* * *}$} & & [0.57] & [0.97] \\
\hline \multirow[t]{2}{*}{ Self-Sufficiency*Solidarity } & & 0.672 & 0.854 & & 1.722 & 10.157 & & -0.031 & -0.12 \\
\hline & & {$[2.60]^{* *}$} & {$[2.35]^{* *}$} & & {$[1.88]^{*}$} & {$[9.08]^{* * *}$} & & [0.22] & {$[0.82]$} \\
\hline \multirow[t]{2}{*}{ Age } & & & -0.002 & & & 0.341 & & & -0.001 \\
\hline & & & [0.25] & & & {$[14.16]^{* * *}$} & & & [0.25] \\
\hline \multirow[t]{2}{*}{ Age*Village bank } & & & -0.012 & & & -0.428 & & & 0.002 \\
\hline & & & {$[0.31]$} & & & {$[3.27]^{* * *}$} & & & {$[0.07]$} \\
\hline \multirow[t]{2}{*}{ Age*Solidarity } & & & -0.021 & & & -0.371 & & & 0.003 \\
\hline & & & [1.52] & & & {$[8.55]^{* * *}$} & & & {$[0.56]$} \\
\hline \multirow[t]{2}{*}{ Size Indicator } & & & 0.432 & & & 3.136 & & & -0.109 \\
\hline & & & {$[3.58]^{* * *}$} & & & {$[8.93]^{* * *}$} & & & [1.94]* \\
\hline \multirow[t]{2}{*}{ Size*Village bank } & & & -0.435 & & & -3.061 & & & 0.074 \\
\hline & & & [1.90]* & & & {$[4.11]^{* * *}$} & & & [0.69] \\
\hline \multirow[t]{2}{*}{ Size*Solidarity } & & & -0.161 & & & -2.109 & & & -0.115 \\
\hline & & & [1.03] & & & {$[4.36]^{* * *}$} & & & [1.65] \\
\hline \multirow[t]{2}{*}{ E. Eur. and Ctrl Asia } & 0.298 & 0.202 & 0.108 & -0.125 & -0.288 & -0.293 & -0.068 & -0.063 & -0.098 \\
\hline & {$[2.58] * *$} & {$[1.83]^{*}$} & {$[0.77]$} & {$[0.35]$} & {$[0.81]$} & {$[0.70]$} & {$[1.15]$} & {$[1.06]$} & {$[1.72]^{*}$} \\
\hline \multirow[t]{2}{*}{ Sub. Africa } & 0.292 & 0.233 & 0.336 & 0.119 & 0.063 & 1.051 & -0.023 & -0.019 & -0.016 \\
\hline & {$[2.57] * *$} & {$[2.17]^{* *}$} & {$[2.61]^{* *}$} & {$[0.26]$} & {$[0.14]$} & {$[2.15] * *$} & {$[0.38]$} & {$[0.31]$} & {$[0.28]$} \\
\hline \multirow[t]{2}{*}{ Middle East and N. Africa } & -0.11 & -0.124 & -0.23 & -1.073 & -1.141 & -1.278 & -0.034 & -0.038 & -0.023 \\
\hline & {$[0.76]$} & {$[0.91]$} & [1.42] & {$[2.12]^{* *}$} & {$[2.30]^{* *}$} & {$[2.34] * *$} & {$[0.45]$} & [0.49] & {$[0.33]$} \\
\hline \multirow[t]{2}{*}{ South Asia } & -0.009 & -0.067 & -0.085 & -0.759 & -0.878 & -0.646 & 0.197 & 0.213 & 0.134 \\
\hline & {$[0.06]$} & [0.52] & [0.56] & {$[1.70]^{*}$} & {$[2.00] * *$} & [1.33] & {$[2.75]^{* * *}$} & {$[2.93]^{* * *}$} & {$[2.00] * *$} \\
\hline \multirow[t]{2}{*}{ East Asia } & -0.041 & 0.013 & 0.032 & -0.514 & -0.431 & -0.97 & 0.026 & 0.029 & 0.141 \\
\hline & [0.31] & [0.10] & [0.19] & |[1.21] & [1.03] & {$[1.85]^{*}$} & {$[0.37]$} & [0.41] & [1.93]* \\
\hline \multirow[t]{2}{*}{ Constant } & 0.509 & 1.053 & 0.472 & 2.193 & 3.607 & 4.811 & 0.424 & 0.431 & 0.399 \\
\hline & {$[3.78] * * *$} & {$[4.96]^{* * *}$} & [1.66]* & {$[4.82]^{* * *}$} & {$[4.89]^{* * *}$} & {$[5.30] * * *$} & {$[5.76] * * *$} & {$[3.60]^{* * *}$} & {$[3.37]^{* * *}$} \\
\hline Obs & 113 & 113 & 108 & 99 & 99 & 94 & 110 & 110 & 104 \\
\hline R-squared & 0.25 & 0.29 & 0.42 & 0.25 & 0.3 & 0.89 & 0.49 & 0.5 & 0.66 \\
\hline
\end{tabular}

All regressions estimated via Robust Regression in STATA.

* significant at $10 \%$; ** significant at $5 \%$; *** significant at $1 \%$ 


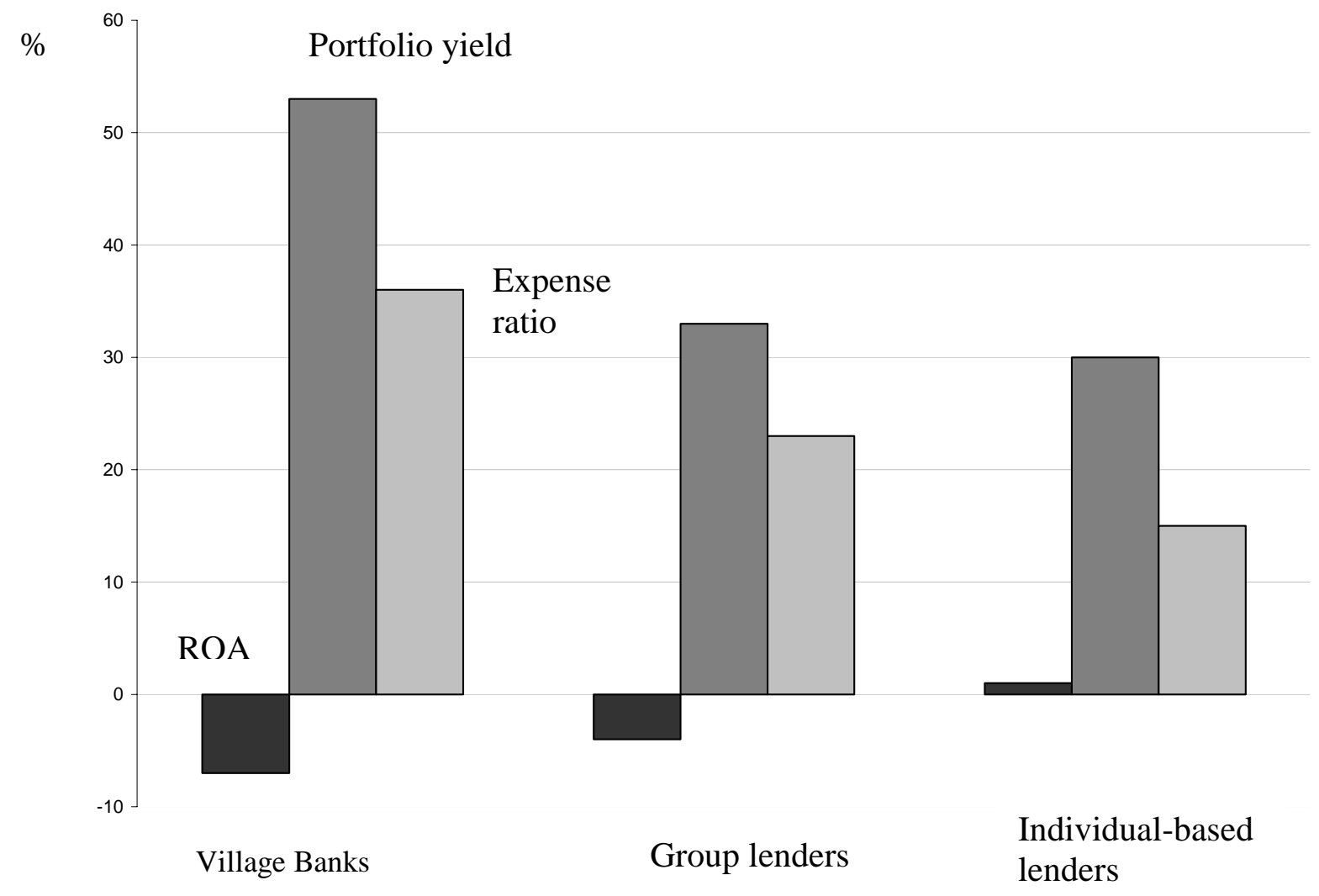

Figure 1: Return on assets (ROA), real gross portfolio yield, and total expense ratio by lending type

Source: Calculated from data in MicroBanking Bulletin, July 2003 (n=124) 
Predicted Trade-off between Financial Self-sufficiency and Gross Yields for Median Individual Lender, from Table 8, Model 3

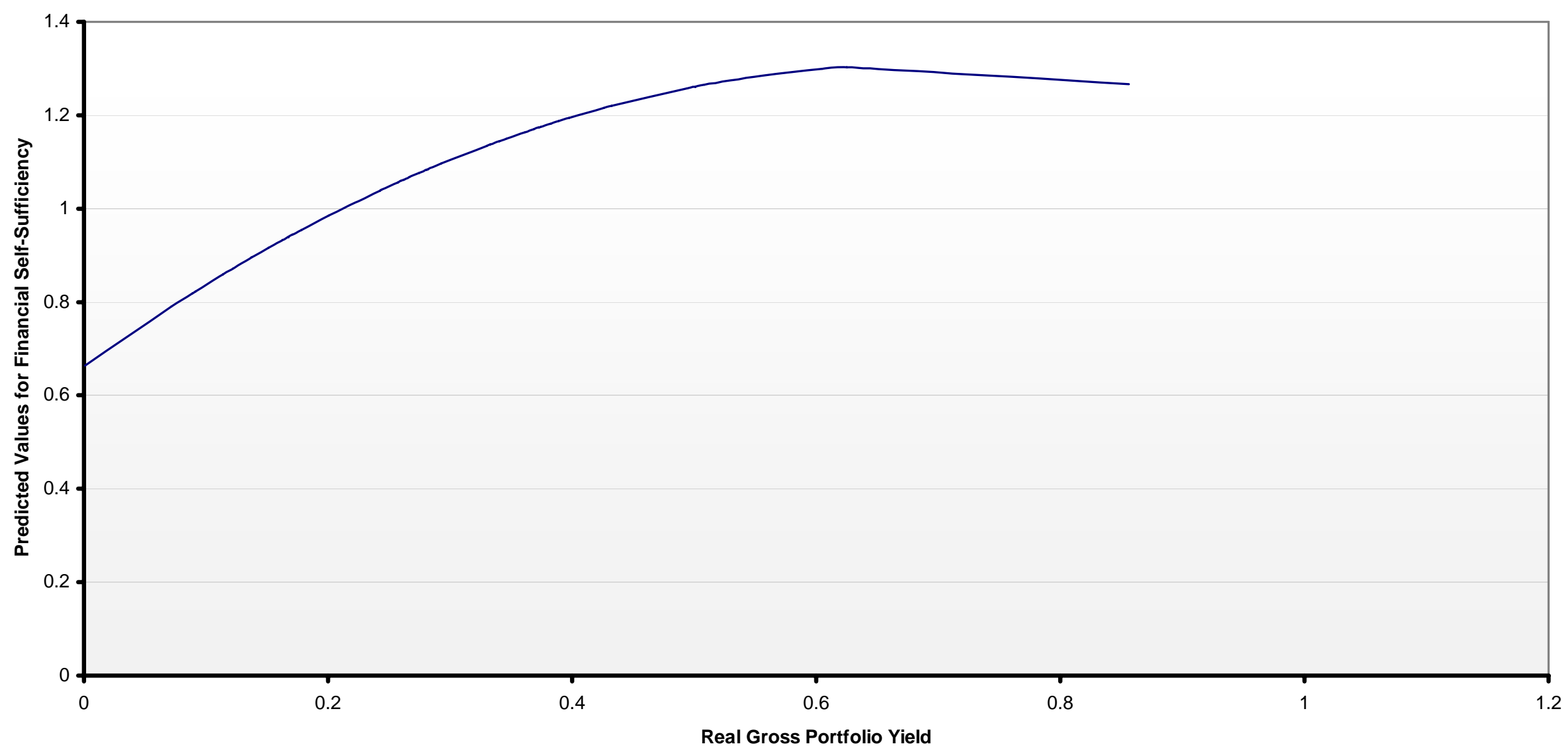

Figure 2. Portfolio Yields and Financial Self-Sufficiency, Individual Lenders 
Predicted Trade-off between Financial Self-sufficiency and Gross Yields for Median Solidarity Group Lender, from Table 8, Model 3

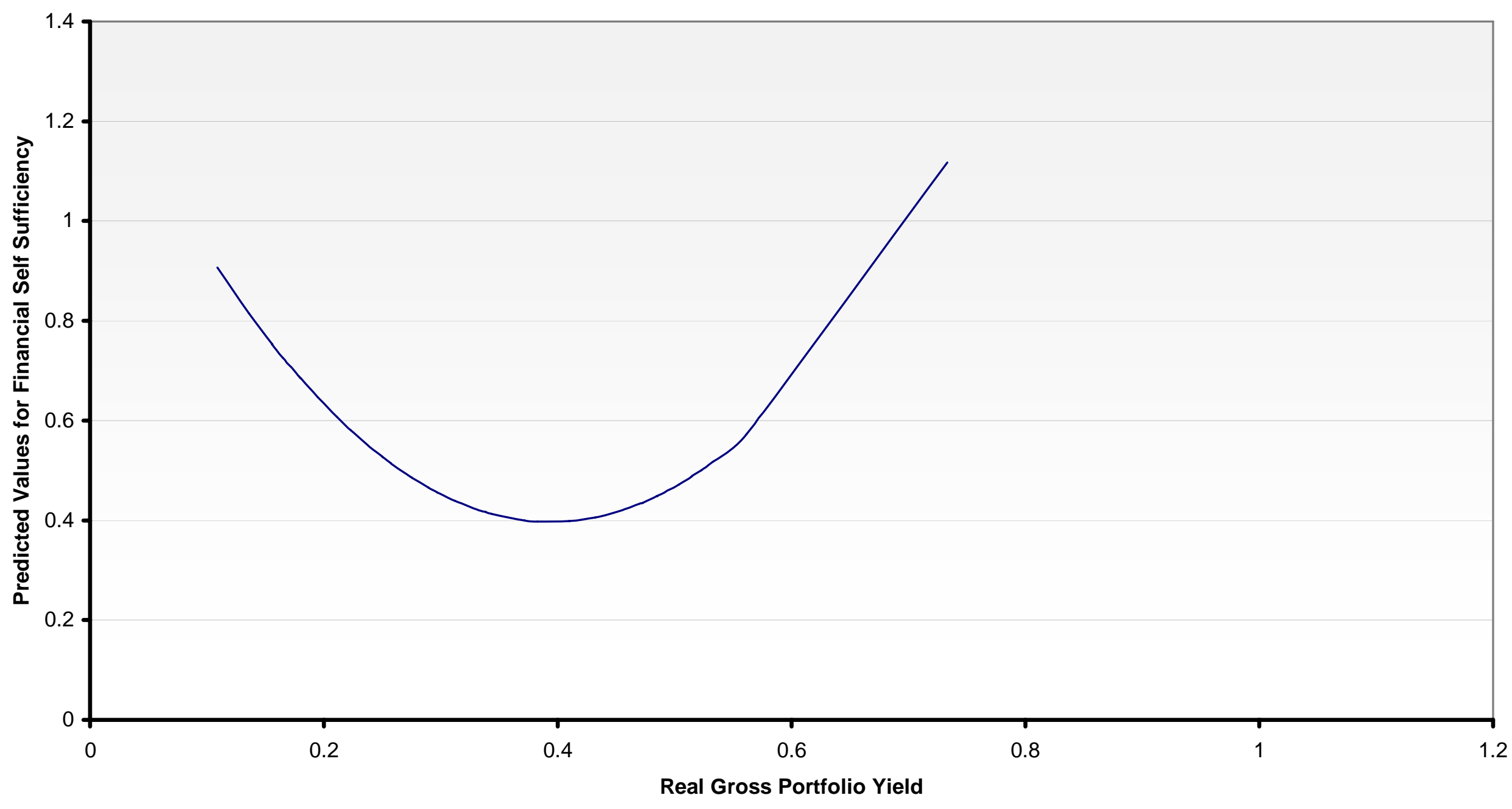

Figure 3: Portfolio Yield and Financial Self-Sufficiency, Solidarity Group Lenders 
Predicted Trade-off between Portfolio Risk and Gross Yields for Median Individual Lender, from Table 9, Model 3

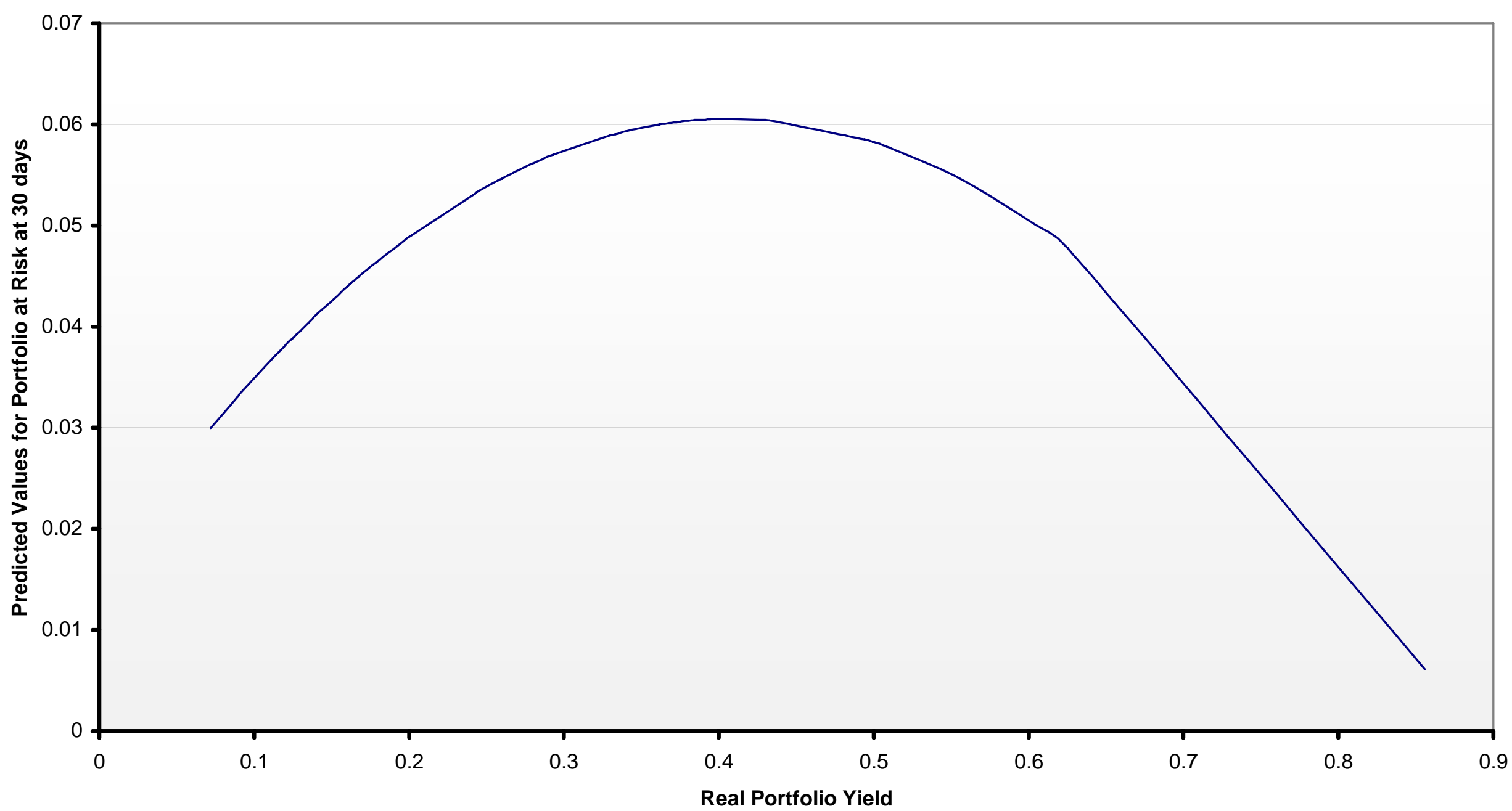

Figure 4: Portfolio Yield and Portfolio at Risk at 30 Days, Individual Lenders 
Predicted Trade-off between Average Loan Size and Total Costs for Median Individual Lender, from Table 10, Model 2

(excludes outliers)

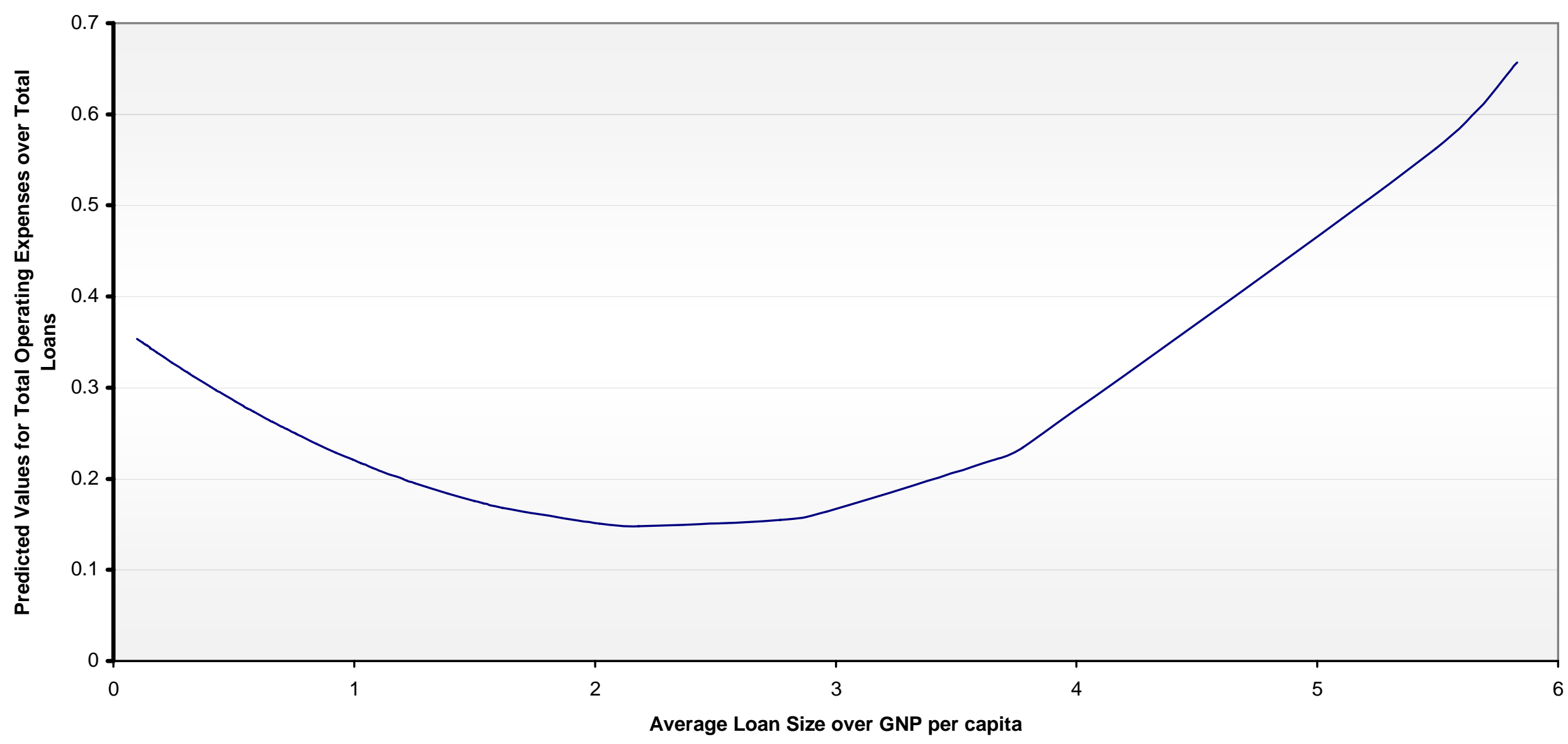

Figure 5: Trade-off, Average Loan Size and Operating Expenses, Individual Lenders 
Predicted Trade-off between Average Loan Size and Total Costs for Median Solidarity Group Lender, from Table 10, Model 2

(excludes outliers)

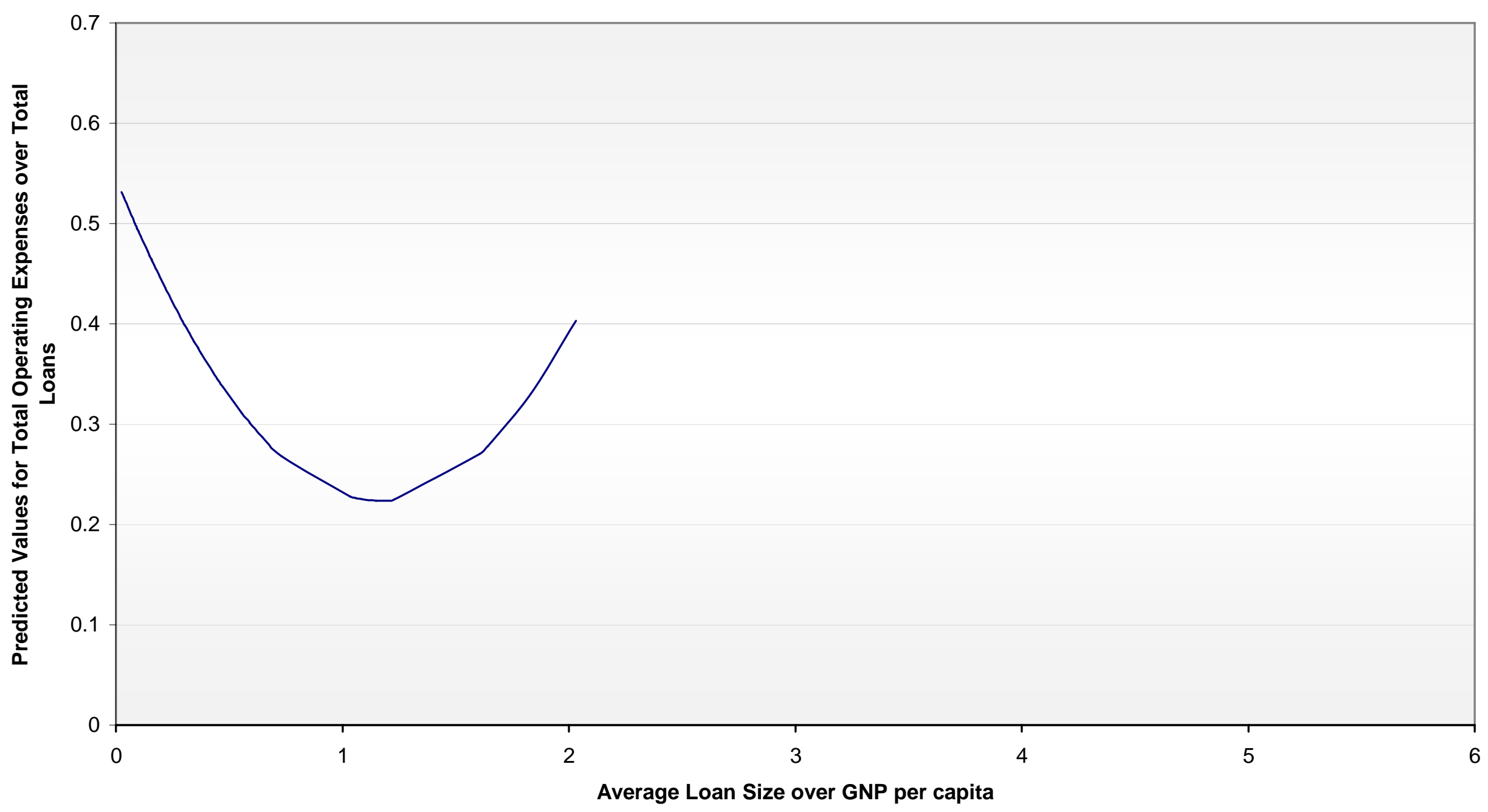

Figure 6: Trade-off, Average Loan Size and Operating Expenses, Solidarity Group Lenders 